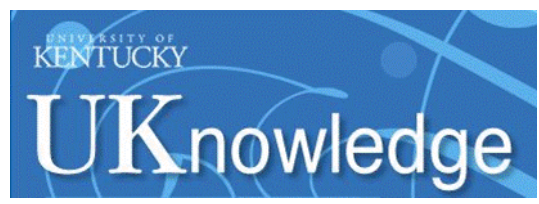

University of Kentucky

UKnowledge

Institute for the Study of Free Enterprise

Working Papers

Institute for the Study of Free Enterprise

$1-2017$

\title{
Hedge Fund Boards and the Market for Independent Directors
}

Christopher P. Clifford

University of Kentucky, chris.clifford@uky.edu

Jesse A. Ellis

North Carolina State University

William C. Gerken

University of Kentucky, will.gerken@uky.edu

Follow this and additional works at: https://uknowledge.uky.edu/isfe_papers

Part of the Finance and Financial Management Commons

Right click to open a feedback form in a new tab to let us know how this document benefits you.

\section{Repository Citation}

Clifford, Christopher P.; Ellis, Jesse A.; and Gerken, William C., "Hedge Fund Boards and the Market for Independent Directors" (2017). Institute for the Study of Free Enterprise Working Papers. 26.

https://uknowledge.uky.edu/isfe_papers/26

This Research Paper is brought to you for free and open access by the Institute for the Study of Free Enterprise at UKnowledge. It has been accepted for inclusion in Institute for the Study of Free Enterprise Working Papers by an authorized administrator of UKnowledge. For more information, please contact UKnowledge@lsv.uky.edu. 


\title{
Hedge Fund Boards and the Market for Independent Directors
}

\author{
Christopher P. Clifford \\ Jesse A. Ellis \\ William C. Gerken
}

January 2017

Institute for the Study of Free Enterprise

Working Paper 3

\author{
University of Kentucky \\ 244 Gatton College of Business and Economics \\ Lexington, KY 40506-0034 \\ http://isfe.uky.edu/
}

\section{Gatton College of


Clifford, Christopher P., Jesse A. Ellis, and William C. Gerken. "Hedge Fund Boards and the Market for Independent Directors.” Schnatter Institute Working Paper. John H. Schnatter Institute for the Study of Free Enterprise, University of Kentucky, Lexington, KY, January 2017.

\begin{abstract}
* $^{*}$
We provide the first examination of hedge fund boards and their directors. The majority of directorships are held by extremely busy independent directors. These directors are sought after by funds because they have more reputational capital at stake, making them independent and credible monitors whose presence can certify fund quality to investors. Busy independent directors are more likely to be hired by high quality funds, and their departure from the board is associated with investor withdrawals. Moreover, funds with busy independent directors are less likely to commit fraud, abuse discretionary liquidity restrictions, or engage in performance-based risk shifting.

Christopher P. Clifford

University of Kentucky

Gatton College of Business and Economics

Department of Finance and Quantitative Methods

Lexington, KY 40506-0034

William C. Gerken

University of Kentucky

Gatton College of Business and Economics

Department of Finance and Quantitative Methods

Lexington, KY 40506-0034

will.gerken@uky.edu

Jesse A. Ellis

North Carolina State University

Poole College of Management

Department of Business Management

Raleigh, NC 27695
\end{abstract}

Keywords: hedge fund, governance, securities and investment

*We thank seminar participants at the $7^{\text {th }}$ Conference on Professional Asset Management (Rotterdam School of Management), Mid-Atlantic Research Conference (Villanova University), Recent Advances in Mutual Fund and Hedge Fund Research (Humboldt University), Symposium on Hedge Funds and Regulation at SUNY Albany, Miami University, Texas Christian University, University of Kentucky, University of Tennessee, West Virginia University, Wilfrid Laurier University, and University of North Carolina at Charlotte. We thank Vikas Agarwal, George Aragon, Naveen Daniel (Discussant), Diane Del Guercio, Stephen Dimmock, Russell Jame, Petri Jylha (Discussant), David Mauer, Shawn Mobbs, Louis Piccotti (Discussant), Martin Schmalz, Chris Schwarz (Discussant), Shawn Thomas, Mark Walker, and Richard Warr for their comments. We would like to especially thank Gary Linford, Don Seymour, Darren Stainrod, and Alan Tooker for providing institutional detail. Gerken acknowledges the support of the John H. Schnatter Institute for the Study of Free Enterprise. We thank Xin Hong, Nathaniel Graham, Qiping Huang, and Emma Xu for research assistance.

Schnatter Institute Working Papers are circulated for discussion and comment purposes. They have not been peer-reviewed through the institute. Working Papers present an author's provisional finding, which, upon further revision, are likely to be republished in an academic journal. The opinions expressed in Schnatter Institute Working Papers reflect the views of the authors and may not represent the opinions of the Schnatter Institute or the University of Kentucky. 


\section{Hedge Fund Boards and the Market for Independent Directors}

\section{Christopher P. Clifford, Jesse A. Ellis, and William C. Gerken}

\section{Introduction}

Hedge funds face limited monitoring from regulators, and their complex investment strategies and opaque disclosures make it hard for their investors to monitor them. Moreover, share restrictions such as lockup periods make it difficult for investors to "vote with their feet" by withdrawing their capital. These characteristics provide fertile ground for agency conflicts to emerge between hedge fund managers and investors. Despite the fact that funds collectively manage over $\$ 3.4$ trillion dollars in assets (SEC Division of Investment Management, 2015) and several recent studies document hedge fund misbehavior ${ }^{1}$, we know relatively little about how funds are governed so as to assure investors can expect a return on their investment. In this paper, we examine the role that boards of directors play in the governance of hedge funds.

Hedge fund directors have a legal obligation to monitor the fund manager and serve as an advocate for investor rights. However, because directors are appointed by the fund manager, critics raise concerns that directors may simply be "rubber-stamps" that serve nothing more than a perfunctory role in fulfilling regulatory requirements to have a board. This view has gained popularity following a wave of scandals during the recent financial crisis, where several directors were accused of breaching their fiduciary duties to properly monitor funds that engaged in misconduct and fraud. ${ }^{2}$ Consequently, several media reports questioned the independence and monitoring capability of hedge fund boards. ${ }^{3}$ Despite this increased media attention, an empirical study of hedge fund boards is notably absent from the literature. This paper is a first step toward filling this gap. To do so, we take advantage of a recent

\footnotetext{
${ }^{1}$ See for example, Agarwal, Daniel, and Naik (2011); Bollen and Pool (2009, 2012); Dimmock and Gerken (2016); Aiken, Clifford, and Ellis (2015); Patton, Ramadorai, and Streatfield (2015)

2 "Former Bear Stearns Managers Face Criminal Charges", Bloomberg, June 2008;

"The Other Offshore Disaster", New York Times, June 2010;

"Weavering Capital Collapses Over Derivatives Position", Financial Times, March 2009

3 "In Caymans, It's Simple to Fill a Hedge Fund Board", New York Times, July 2012;

"Hedge Funds Are Not Like Banks", New York Magazine, July 2012
} 
disclosure law that forces hedge funds to electronically report their board membership to the Securities and Exchange Commission (SEC). We use these SEC filings to build a database comprised of 5,400 different directors for 5,126 hedge funds over the period 2009-2013.

We begin by documenting several stylized facts about hedge fund boards. Unlike public corporations and mutual funds, hedge funds face few governance regulations and thus offer an interesting setting to understand how market forces shape board structure. In most cases, a hedge fund's board would be compliant with regulations if it had just two inside directors (i.e., fund owners, employees, or related parties) and no outside directors. If the role of hedge fund boards was simply to comply with regulations, then we would expect to see limited variation in board structure, few outside directors, and significant clustering around regulatory minima. Strikingly, the data plainly contradict this "compliance" hypothesis. We find considerable cross sectional variation in the size and structure of hedge fund boards. In fact, despite the lack of independence requirements, outside directors are more common than inside directors and, though most boards have only three directors, nearly $80 \%$ have at least one outside director.

Another interesting pattern emerges when we examine the workloads of these outside directors. Namely, the majority of outside directors sit on relatively few boards, yet the majority of directorships are held by a relatively small yet busy cadre of professional directors, each of whom hold more than twenty directorships at one time. The media point to these busy directors as evidence that hedge fund board governance is perfunctory- such a heavy workload must preclude directors from devoting the time and attention necessary to protect investors. ${ }^{4}$ In this paper, we put forth an alternative explanation for the busyness of hedge fund directors based on the concepts of director reputation and certification.

Investor concerns over agency problems and withdrawal restrictions motivate hedge funds

\footnotetext{
4 "Fund Jumbo Directors and Their Many Seats", Financial Times, November 2011
} 
to hire credible, independent monitors to help certify their quality and encourage outside investment. However, because fund managers hire them, directors need an external source of credibility in order to help convince investors that they are appropriately monitoring the manager. The labor market should reward higher quality directors with more directorships, and busier directors have more reputational capital to lose if they neglect their fiduciary duties by "rubber-stamping" the decisions of the fund manager. Additionally, directors that work for many different fund advisers are less beholden to any single employer, making them more independent from fund management. Thus, we hypothesize that directors can derive their credibility from the director labor market, meaning that the busyness of a director can serve as a proxy for his quality, reputational capital, and independence from management.

To test this theory, we first examine the relation between a director's reputation and his future job prospects. We find that the probability a director is appointed to a new directorship is strongly and positively related to the number of other directorships he holds. Additionally, directors are hired more often if they served on the boards of better performing funds and less often if they served on the board of a failed fund. Collectively, these results are consistent with the theory that funds are attracted to directors that have developed stronger reputations in the director labor market. In contrast, we find several results which are inconsistent with the rubber-stamp theory that funds prefer directors that are too busy to monitor them. Specifically, we find there is diminishing returns to director busyness, suggesting capacity costs are a real concern for directors. Moreover, funds are more likely to hire directors with more fund-specific human capital and lower monitoring costs, indicating funds and directors match in such a way as to mitigate capacity costs.

Another way that hedge fund directors increase their workload capacity is by working for professional directorship firms that employ several directors and a support staff. The majority of directorships are held by affiliates of a directorship firm, and this institutional structure appears unique to the hedge fund directorship market. Firm-affiliated directors 
have access to shared resources and technologies that create economies of scale and reduce the marginal cost of monitoring each fund. Busier directors are substantially more likely to work for a firm and are also more likely to concurrently serve on the same board with a colleague from the same firm, reducing the joint workloads of both directors. Working for a firm can also convey additional reputational benefits to the director, as he is able to associate with the collective reputation of the firm and its employees (Tirole, 1996). Even when we control for the director's individual reputational capital, directors from directorship firms are more likely to be hired, and this effect is stronger when the firm is more reputable.

We also find evidence of positive assortative matching between high quality directors seeking to enhance and protect their reputation and high quality funds seeking certification from a credible outside monitor. Specifically, busier directors are more likely to join the boards of better performing funds and funds with fewer regulatory violations. Moreover, funds that lose the certification of a reputable independent director experience a $4.7 \%$ outflow of capital in the quarter of the director's exit. In contrast, we find no outflow of capital when a non-independent director exits or when the fund is able to replace a departing independent director.

We also find evidence that reputable independent directors are better monitors. Specifically, funds with reputable independent directors are $83 \%$ less likely to commit fraud. In addition, funds with reputable independent directors are less likely to abuse discretionary liquidity restrictions (commonly known as side pockets or gates) and engage in performance-based risk shifting. Collectively, our evidence suggests reputable independent directors play an important monitoring role in hedge fund governance.

As the first, large-scale study to examine hedge fund boards and the market for their directors, we contribute to the growing literature which examines the various governance 
mechanisms hedge funds use to manage agency conflicts. ${ }^{5}$ For instance, some studies have found a positive association between fund misconduct and the quality of internal controls such as signature processes governing cash transfers, pricing and disclosure practices, and the quality of service providers such as auditors or administrators (Cassar and Gerakos, 2010; Brown, Goetzmann, Liang, and Schwarz, 2012). Because the board is tasked with developing and monitoring internal control processes, understanding board quality is necessary to understanding the source of effective internal controls. Our findings suggest that the quality of a hedge fund's board can be measured by the reputation and independence of the fund's directors.

In addition, our study is related to the corporate board literature debating the costs and benefits of director busyness. Fama and Jensen (1983) contend that higher quality directors will be rewarded by the labor market with more directorships. Consistent with this reasoning, some studies have used the number of directorships held by a director as a positive indicator of his reputation(e.g., Kaplan and Reishus, 1990; Vafeas, 1999; Masulis and Mobbs, 2011; Field, Lowry, and Mkrtchyan, 2013). Our results are more consistent with this bright side view of director busyness.

However, there is also a potential dark side to director busyness. For example, in their theory of venture capitalist (VCs) involvement in their portfolio companies Kanniainen and Keuschnigg (2003) argue that because it is costly for venture capitalists (VCs) to provide advice to to their portfolio firms, there is an optimal level of busyness, and VCs that become stretched too thin can actually destroy firm value. Supporting this view, Cumming (2006) finds that VCs tend to have smaller portfolios when their portfolio companies require more intensive involvement by the VC. Moreover, Cumming and Walz (2010) find that busy VC

\footnotetext{
${ }^{5}$ Some examples include: Brown, Goetzmann, Liang, and Schwarz (2008, 2012), Agarwal, Daniel, and Naik (2009), Cumming and Dai (2010), Dimmock and Gerken (2012), Cumming, Dai, and Johan (2013), Ozik and Sadka (2014), and Aiken, Clifford, and Ellis (2015)
} 
managers tend to have worse performance. There is also evidence of a dark side to busyness for public corporations. Fich and Shivdasani (2006) find that firms with a high proportion of busy directors are associated with weak corporate governance and poor firm performance, and Yermack (2004) finds that the labor market is less likely to reward busier directors with additional directorships.

The discrepancies between the findings in our study and studies revealing a dark side to director busyness could be due to the fact that the latter studies focus on directorships for typical industrial corporations, which require high firm-specific workloads that dramatically lower a director's capacity to effectively manage multiple board positions. This makes a corporate director's busyness a poor proxy of his quality, because we do not observe the seats directors could obtain in the absence of these constraints (e.g., if they had more free time or could specialize in closely related firms). In contrast to industrial corporations, hedge funds are relatively homogenous, and the duties of their directors are relatively focused and standardized. These factors dramatically reduce the required time investment and increase the scalability of the director's human capital such that it can be employed efficiently across many funds. ${ }^{6}$

\section{Data and Institutional Background}

\subsection{Data Sources}

The board data in our paper are collected from SEC Form D filings from EDGAR over the period of 2009 to $2013 .^{7}$ All hedge funds seeking to raise capital from U.S. investors must file a Form D disclosing limited information about the fund and the offering, including the names and addresses of the fund's board members. We define a director as being an

\footnotetext{
${ }^{6}$ See section 2.3.1 for a further discussion of how hedge fund directors are able to manage heavy workloads. ${ }^{7}$ The beginning of our sample period coincides with the SEC moving to electronic Form D filings on March 15, 2009. See Ivanov and Bauguess (2012) for a summary of these data.
} 
insider if the director also lists himself as an executive of the fund, the director discloses a relationship with the fund, or the director matches to other regulatory filings for the fund. Otherwise, we classify the director as an outsider. The focus of our study is on this sample of outside directors. We manually collect background data on outside directors from the Form D, LinkedIn, web searches, and FundGov, a commercial database that includes biographical information of hedge fund directors. We combine our director data with two other datasets: a dataset derived from Form ADV filings and a merged database of the five most widely used commercial hedge fund databases: LipperTASS, HFR, Morningstar, BarclayHedge, and Eureka.

\subsection{Hedge Fund Boards}

Nearly $70 \%$ of hedge fund assets are held by offshore corporations (offshore funds) located in countries such as the Cayman Islands, Bermuda, and the British Virgin Islands. Though most of these funds are managed by U.S.-based hedge fund advisers, they are located offshore to serve the U.S. tax-exempt and non-U.S. investor clienteles, both of whom can receive favorable tax treatment and enhanced privacy when they invest through an offshore corporation. Offshore funds structured as corporations must comply with corporate and securities laws in these countries, including the requirement that the fund must have a board of directors.

To serve the U.S. taxable investor clientele, advisers set up domestic limited partnerships (onshore funds) to avoid the double taxation that accrues to domestic investors in U.S. corporations. In a limited partnership, the fund manager serves as the general partner with full managerial control, and the investors serve as limited partners. Limited partnerships do not have boards because, by definition, limited partners cannot participate in control over fund operations. Therefore, tax laws essentially preclude boards in onshore hedge funds, whereas they essentially force the establishment of boards in offshore hedge funds. Thus, our 
analysis is restricted to the boards of offshore funds. ${ }^{8}$

In Table 1, we present summary statistics and frequency distributions of board structures and offshore domiciles for the 5,126 funds in our sample. By far the most common domicile for offshore hedge funds is the Cayman Islands, which accounts for $79.6 \%$ of the sample. The next two largest domiciles are the British Virgin Islands (7.8\%) and Bermuda (4.0\%), respectively. These domiciles impose relatively few regulations regarding the structure of hedge fund boards, and unlike U.S. public corporations and mutual funds, offshore hedge funds are not typically required to have any outside directors on their board. In the Cayman Islands, for example, the only requirement is that boards have at least two directors (inside or outside). If boards were designed simply to meet the regulatory minimum of their respective domicile, then we would expect to see limited variation in board structure, few outsiders, and significant clustering around regulatory minima.

The statistics in Table 1 plainly contradict this "compliance" hypothesis. Despite the lack of outsider requirements, outside board members are actually more common than inside board members. From Panel A, we see that the median board has three directors, one of which is an insider and two of which are outsiders. Indeed, $79.2 \%$ of boards have at least one outside director. Panel B reveals that the two outsider, one insider structure is the most common board structure, yet it also reveals considerable variation in board structure across funds.

\subsection{Hedge Fund Directors}

Although hedge fund board structures are relatively unregulated, hedge fund directors face fiduciary duties and responsibilities that are shaped by industry standards and domicile

\footnotetext{
${ }^{8}$ We note that onshore funds could obtain de facto board governance when they are part of a master-feeder structure, whereby the onshore fund feeds its assets to an offshore corporate master-fund. This master-feeder structure is common in the hedge fund industry, and we include the boards of these offshore master funds in our sample as well.
} 
common law. Hedge fund directors have a general duty to supervise matters where the interests of the manager and investors may differ. Directors help establish internal controls, review and approve the investment advisers' contracts and fees, and help appoint the fund's auditor, custodian, and other third party administrators. The directors also approve certain actions taken by the fund, such as the valuation of illiquid assets, in-house trades with the investment adviser, certification of the accuracy of fund information, the granting of side letters for preferential treatment of certain investors, and approval of discretionary liquidity restrictions (i.e., gates or side pockets). Despite having these duties, hedge fund directorships typically require considerably smaller time commitments than directorships of public corporations and their fees are relatively small $(\$ 10,000$ to $\$ 30,000$ per hedge fund board compared to $\$ 227,000$ per board for directors of the typical Fortune 500 company (Tower Watson Survey, 2013). The busiest hedge fund directors are "professional directors" that derive their primary income from serving as a director on many funds.

Table 2 summarizes the characteristics of the 1,573 outside hedge fund directors in our sample and reveals several striking facts about the director labor market. Panel A describes the director's country of residence. Interestingly, despite the fact that our sample is comprised of non-U.S. funds by construction, the United States is the most common country of residence for directors $(27.8 \%)$. Under a quarter $(24.2 \%)$ of directors live in the three most popular fund domiciles (Cayman Islands, British Virgin Islands, and Bermuda), despite the fact that over $90 \%$ of funds are domiciled in these locations.

Panels B and C of Table 2 summarize director workloads at both the director and directorship level. These panels reveal that the distribution of director workloads is considerably skewed. In Panel B we see that the average outside director sits on 6.5 boards, while the average outside directorship is held by a director that sits on 41.0 boards. In Panel $\mathrm{C}$ we see that $67.6 \%$ of outsider directors serve on three or fewer funds, which resembles the typical workload of corporate directors. However, these directors account for only $17.9 \%$ of all outside 
directorships. The remaining $82.1 \%$ of directorships are held by only $32.4 \%$ of the outside directors. Strikingly the $7.5 \%$ of directors that sit on more than twenty boards collectively hold $51.4 \%$ of all outside directorships. Thus, the majority of directorships are held by directors that are extraordinarily "busy" by typical corporate director standards.

Directors also sit on boards across many different advisers. ${ }^{9}$ The average outside directorship is held by a director that represents 22.7 different advisers. This statistic is pertinent to the concept of director independence. A director who serves on many boards for the same adviser is more likely to be co-opted by that adviser, as his collective compensation is derived from one employer. Thus, we define an outside director to be Independent if he sits on the boards of funds managed by multiple advisers and the director is not conflicted by providing other services to the fund such as legal or audit work. Independent directors make up 35.0\% of the outside director population, and hold $78.7 \%$ of the outside directorships. ${ }^{10}$ In our subsequent analysis we separately examine both the number of funds and the number of advisers a director works for to highlight the link between multiple adviser associations and director independence.

\subsubsection{How can hedge fund directors manage so many directorships?}

Considering that directors of public corporations are often considered "busy" if they hold more than three directorships (Fich and Shivdasani, 2006), it is reasonable to ask how hedge fund directors can serve so many funds at once. Although hedge funds operate varied

\footnotetext{
${ }^{9}$ Hedge funds are managed by an adviser which is essentially an umbrella company that manages several underlying funds. The analog in mutual funds would be the mutual fund family, such as Fidelity, which manages several underlying and disparate Fidelity funds, each with their own board. While mutual fund directors routinely sit on many boards concurrently, these boards are typically on funds within the same family. For example, three unique directors serve as outside directors across 39 unique Fidelity Select funds. Each of these directors, however, does not serve across additional mutual fund families, such as Vanguard or T. Rowe Price.

${ }^{10}$ One concern is that directors may work with many advisers but all work for the same fund administrator that has a stable of directors that they place on the fund. In fact, the busiest directors in our sample work with many service providers, and directors rarely work with only a single service provider of any type.
} 
investment strategies, from a director's perspective, hedge funds are far more homogenous than industrial corporations. Compared to corporate directors, hedge fund directors have a relatively limited set of duties (such as monitoring valuation and trading practices) which require similar knowledge to execute across different hedge funds. Moreover, the majority of agency and regulatory issues facing hedge funds are common across funds, which allow for economies of scale in monitoring several hedge funds at once. In addition, there are several unique aspects of the hedge fund directorship market that enable directors to shoulder ostensibly extreme workloads. We present statistics in Panels D and E that shed light on some of these institutional details.

In Panel D, we present statistics on director backgrounds from data hand collected from their LinkedIn profiles. Typically, directors rely on information generated by fund service providers such as auditors and administrators to evaluate fund management. As we see in Panel D of Table 2, many directors have a background in fund management (39.1\%), accounting $(8.2 \%)$, or law $(8.5 \%)$, which may help them to better process the information these service providers generate in advance of board meetings. Moreover, repeated interactions with these providers across different funds may reduce their information acquisition costs due to familiarity. Thus, once a director acquires the general knowledge required to monitor hedge funds effectively, it can be applied broadly across multiple directorships more easily than if he were the director of a public corporation.

Further, hedge fund directors mitigate capacity problems by organizing themselves into professional service firms (similar to law and accounting firms), whereby the firm employs several directors, and the fund contracts with the firm to provide director representation on the board. By being part of a firm, directors have access to shared resources and technologies that create economies of scale and reduce the marginal cost of monitoring each fund.

The directorship firm, DMS, which is the largest directorship firm headquartered in the Cayman Islands, provides a useful case study. DMS has over 200 employees, and services over 
800 different funds whose assets total $\$ 330$ billion. The directors at DMS share a common support staff which reduces the administrative burden related to servicing each fund. In addition, DMS employs a variety of technological solutions that the directors use to track and evaluate hedge fund trading and valuation practices, which they use to make judgments about fund operations. The costs of technological assets (like a custom software program) are mainly fixed and can be spread across the firm's client base. Further, DMS operates a team-based model, whereby each director is supported by associates working behind the scenes, and sometimes by another DMS director on the board. Multiple DMS directors may sit on the same board, which allows them to work as a team, split up tasks, and reduce the per-person effort required to monitor the fund. Though this firm model is common to the accounting and legal professions, hedge fund directors are the only directors we are aware of that organize themselves in this way.

Panel E of Table 2 shows the proportion of directorships held by directors employed by directorship firms stratified by the busyness of the director. Only $19.8 \%$ of directors with three or fewer directorships work for a firm, whereas $60.2 \%$ of directors with four or more directorships work for a firm. In fact, $81.1 \%$ of the busiest directors (directors with over twenty directorships), work for a directorship firm. This is consistent with the idea that directorship firms are a means by which busy directors can manage capacity issues. Busier directors are also much more likely to serve with a teammate, which we define to be the cases where a director sits on a board concurrently with one or more colleagues from the same directorship firm. Directors who manage over twenty funds serve with a teammate $42.4 \%$ of the time, compared to only $7.0 \%$ of the time for directors with three or fewer funds, suggesting that the team-model is one way in which membership in a directorship firm enables directors to share and manage heavy workloads. 


\section{Reputation and the Labor Market for Hedge Fund Directors}

\subsection{Hypothesis Development}

There are at least three reasons why busier directors should have higher value in the labor market. First, Fama and Jensen (1983) contend that higher quality directors will be rewarded by the labor market with more directorships. Thus, the size of a director's portfolio of directorships could be a proxy for his quality. Second, a large portfolio of directorships can also serve as a reputational bonding mechanism. A director that work for more funds has more to lose by acting in a way that hurts his reputation (i.e., by failing to properly monitor a fund). Third, directors that work for many managers are less beholden to any single manager, and thus are more independent from management. Coles, Daniel, and Naveen (2014) argue that outside directors that are appointed by management are likely to be captured by the very managers they are supposed to be monitoring. However, a director that serves on many boards has little incentive to cater to a particular manager if in doing so it would tarnish his reputation. A director who can be credibly perceived by investors as being more independent could provide valuable certification for the fund. This leads us to our first hypothesis:

Hypothesis 1a Directors are more likely to obtain additional directorships if they have worked for more funds and more advisers.

In addition to the quantity of directorships, the quality should matter as well. If hedge funds care about hiring quality directors, then we should see evidence that the labor market rewards directors for that have worked for better performing funds (Fama and Jensen, 1983). Moreover, Fama and Jensen (1983) predict that there can be a substantial devaluation of human capital if a director develops a poor reputation. Fund failure is a particularly important risk for hedge fund investors, and performance track records will not include the impact of fund failure as hedge fund databases can be missing the worst returns of hedge funds that fail and stop reporting (Aiken, Clifford, and Ellis, 2013; Agarwal, Fos, and Jiang, 
2013). Thus, funds should be less willing to hire directors that worked for a failed fund in the past.

Hypothesis 1b Funds are more likely to hire directors from better performing funds and less likely to hire directors that have worked for failed funds.

A third dimension of director reputation comes from the reputation of the directorship firms. Tirole (1996) theorizes that a group member's reputation and incentives are affected by his own past behavior, as well as by the behavior of the group, and vice-versa. Because the reputation of the group (directorship firm) is influenced by the behavior of the members (directors), the group has an incentive to monitor each member to ensure that he provides appropriate product quality (monitoring) and does not adversely impact the group's collective reputation. In other words, a director from a firm will not only worry about protecting his own reputation when carrying out his duties, but will also worry that the firm may fire him if he shirks his responsibilities. Thus, a hedge fund and its investors can use the directorship firm's reputation to infer the expected quality of director services. Moreover, just as the director's own reputation is the bonding mechanism that incentivizes his monitoring effort, the firm's reputation can act as an additional layer of "skin in the game" that will encourage the director to provide quality monitoring.

Hypothesis 1c Directors are more likely to obtain new directorships if they work for directorship firms and this effect should be stronger when the director works for more reputable firms.

\subsection{Results: Directorship Appointments}

In this section, we test our hypotheses concerning the role of reputation in the market for directors. In Table 3, we identify the attributes that are related to a director's propensity to

obtain an additional directorship in the following quarter. We employ a logit model, where 
the dependent variable is equal to one if the director joins at least one additional board in the subsequent quarter, and zero otherwise. The sample includes all outside directors and the unit of observation is the director-quarter. In all models, we control for time fixed-effects and cluster the standard errors by director.

Model 1 reveals that the number of directorships the director currently holds is positively related to the likelihood that a director acquires a new directorship in the subsequent period. For example, holding an additional directorship is associated with a roughly $9 \%$ increase in the odds of a directorship appointment in the next quarter. A director with a single directorship has only a $5 \%$ probability of adding at least one additional directorship in the next quarter, while a director with twenty directorships has a $50 \%$ probability of joining additional boards. This result is consistent with the idea that the size of a director's portfolio of directorships is a proxy for the quality of a director's reputation.

However, directors have a finite amount of time to devote to each fund, and taking on too many directorships may limit the director's monitoring capacity. Survey evidence (Carne Global Financial Services, 2011) suggests that fund managers and investors have such concerns. The majority of respondents replied that the optimal director should have no more than 20-30 directorships. Interestingly, few $(<5 \%)$ respondents replied that directors should have less than twenty directorships, while a similar proportion replied that more than fifty is optimal. Thus, while reputation-based arguments suggest a director's quality should be increasing in the number of directorships he holds, this relation should weaken as directors become increasingly busy.

In Model 2, we test for a non-linearity in the relation between the number of current directorships and the likelihood that a director acquires a new directorship using a piecewise linear specification estimated over three regions of current directorships (1-3, 4-20, and 21+). We find that the relation between future appointments and current directorships is strongest in the lower regions (1-3 and 4-20), and the relation significantly weakens in the upper region 
(a comparison of all three coefficients shows the differences are significant with a $p$-value $<$ 0.001). That is, an increase in directorships (i.e., increase in reputational capital) matters most for directors that do not hold many directorships to begin with. Directors that already have more established reputations (sit on more than twenty boards) realize little additional reputational benefits by serving on additional boards. This implies the net reputational benefit of director busyness exhibits diminishing returns. It could be that extremely busy directors have more reputational capital than less busy directors, but the additional capacity costs of extra directorships may offset some of the reputational benefits.

In Model 3, we use the number of advisers the director works for (as a director) as a proxy for director quality instead of the number of directorships. This proxy is potentially more powerful than the raw number of directorships because, in addition to being more reputable, directors that work for more advisers are also likely to be more independent. We find a strong positive and significant relation between number of advisers and appointment probability. Specifically, working for an additional adviser increases the the odds of a directorship appointment by over $18 \%$.

In Model 4, we explore the relation between the past performance of the funds in the director's portfolio and appointment probability. We continue to control for number of advisers and also include the variable Director Return, which is the director's equal-weight "portfolio" return over the past three years across all funds for which the director serves (we find similar results using alternative estimation windows). We also include Past Failures, which is the number of failed funds (defined as exit from the commercial databases) on which the director served, scaled by the maximum number of funds the director has previously served on. We find a significant and positive (negative) relation between Director Return (Past Failures) and directorship appointment probability.

Finally, we examine the importance of directorship firms. As argued above, if directorship firms convey reputational benefits through a collective reputation channel, then we should 
see an incremental benefit for affiliating with directorship firms. In Model 5, we include Directorship Firm, which is an indicator variable equal to one if the director works for a directorship firm, and zero otherwise. We find that firm-affiliated directors are more than three times as likely to gain an additional directorship as are unaffiliated directors. Including Directorship Firm does not reduce the significance or substantially alter the magnitude of the number of advisers variable, suggesting that the director is still more likely to be hired the more popular he is, regardless of whether or not he works for a firm. Further, we add a proxy for the reputational capital of the firm, Directorship Firm's \# of Funds, which is the number of funds serviced by the firm. This variable is also positive and significant, indicating that directors are more likely to be hired if they come from firms with more clients. For example, a director from one of the ten largest directorship firms (in terms of the number of fund clients) is $79.3 \%$ more likely to obtain a new directorship than a director from a less reputable firm. These results support the hypothesis that directorship firms convey reputational benefits through a collective reputation channel.

\subsubsection{Robustness}

In Table 4, we assess the robustness of our results to changes in sample construction and control variables inclusion. One concern is that the population of director residents could be driving the results. For instance, the majority of funds are domiciled in the Cayman Islands. If it were the case Cayman funds only hired Cayman directors, then our results may be driven by domicile population effects. To address this, in Panel A we present director-level appointment regressions for each director country of residence subsample. We find a similar significant and positive relation between number of advisers and appointment probability across each country subsample, including the United States, where no offshore hedge funds are domiciled. Thus, our results are not being driven by domicile population effects.

Another concern is that our measure of reputational capital is a proxy for other observable 
factors related to director quality. For example, it could be that directors obtain more directorships due to having advanced degrees or certain industry experience, leading to a spurious relation between busyness and appointment probability. To address this, we use the subset of directors with hand collected biographical data from LinkedIn. Specifically, we include the director's age and gender, as well as indicators for whether the director: has a graduate degree, graduated from a top 100 university, has a CFA, was a CEO, or has experience in either private equity, law, fund management, or accounting. We present the results in Panel B of Table 4.

In Model 1, we run our director appointment regressions including each biographical variable and no reputational capital proxy. Of the ten biographical variables, only Age and Fund Experience are significant. Specifically, younger directors and directors with fund experience are significantly more likely to be appointed than older directors or directors without fund experience. This regression has fairly low predictive power, with a pseudo $\mathrm{R}^{2}$ of about 0.03. In Model 2, we add our measure of director busyness (number of advisers) and continue to find a positive and significant relation between number of advisers and appointment probability after controlling for ten other observable director attributes. The addition of this variable greatly increases the predictive power of the regression, as the pseudo $\mathrm{R}^{2}$ increases to 0.19 . Thus, it does not appear that director busyness is merely a proxy for other observable director quality metrics. That said, our results are consistent with director busyness being a proxy for the underlying quality of the director, which may be related to other characteristics that are unobservable to the empiricist (such as intelligence, creativity, business contacts, etc.). The logic behind using director busyness as a proxy for director quality is that the directorship market should reveal the quality of directors, even if other observable characteristics do not. 


\section{Director and Fund Matching}

In the previous section, we implicitly characterized the directorship market as one-sided with funds choosing directors and director human capital being regarded equally across all funds. However, the market is actually characterized by two-sided matching, with funds appointing directors and directors agreeing to work for funds. For instance, a fund may prefer hiring one director over another because his skills and experience make him a better fit for that fund's specific needs (Denis, Denis, and Walker, 2015). Knyazeva, Knyazeva, and Masulis (2013) show that proximity to larger pools of local director talent leads to more independent boards in a sample of US industrial firms. In addition, higher quality funds may have an advantage in attracting higher quality directors if directors are capacity constrained and/or concerned that working for lower quality funds could harm their reputation. In this section, we examine how director hiring decisions are influenced by the interaction between the characteristics of funds and directors.

\subsection{Hypothesis Development}

We expect that funds will seek to hire directors with more fund-specific human capital, i.e. those with attributes or experience that complement the specific operating landscape of the fund. Moreover, such directors bear a relatively lower marginal cost in accepting the position, allowing them to serve on more funds. Thus directors should also prefer to work for funds that match their human capital. with more fund-specific human capital should We examine fund-specific human capital along four dimensions.

First, we predict that directors are more likely to be hired if they have experience working with the fund's adviser in the past. A director with adviser-specific knowledge may be able to invest less monitoring effort in order to understand the idiosyncratic characteristics of the fund, since many of those characteristics are likely shared by the adviser's other funds. This should reduce the director's costs and improve his efficacy as a monitor. Further, the 
director's quality is less uncertain from the adviser's perspective, which should reduce the risk of adding him to the fund's board.

Second, we predict that directors are more likely to be hired if they have experience working with the fund's administrator or other key service providers. In order to monitor the fund's actions, the director must frequently engage with and monitor the fund's service providers. For instance, fund administrators generate comprehensive reports about fund trading and valuation practices, and the director must read and interpret the administrator's findings to understand whether the fund is operating in the interests of its investors. A director who has worked with the administrator in the past can understand their reports within the context of the other reports he has received, improving his ability to make an informed evaluation of the administrator's findings. Further, a director who has a relationship with a service provider may be able to extract critical soft information about fund actions, improving his ability to monitor.

Third, we predict that directors are more likely to be hired if they have more experience with funds that operate similar investment strategies. Many hedge funds concentrate their operations in highly specialized trading strategies. The valuation and reporting issues that are relevant to merger arbitrage funds may differ from the issues relevant to funds trading illiquid debt instruments. Dass, Kini, Nanda, Onal, and Wang (2014) argue that directors with related industry experience can better process firm-specific information, improving their monitoring ability. Similarly, a director whose past experience is more closely aligned with the fund's investment strategy should be in a better position to evaluate the fund's actions.

Fourth, we predict that directors that reside in the same domicile are more likely to be hired by the fund. Although directors need not hail from the same domicile as the fund (indeed, the most common residency is the United States, which has no offshore funds), those that do have a distinct advantage in that they can attend meetings at a significantly lower cost. 
Hypothesis 2a Directors and funds are more likely to match if the director is local and if the director has more experience with the fund's adviser, fund's service providers, and funds that operate similar investment strategies to the hiring fund.

In addition to matching based on monitoring cost minimization, directors and funds may also match based on their quality. While a fund may desire to hire a highly reputable director, that director could choose not to work for that particular fund if it would not help their career or if they have a better outside option. Similarly, while a director may desire to serve on the board of a well-run hedge fund, that fund might not be willing to hire that director. Higher quality funds should have an advantage in attracting higher quality directors if directors are capacity constrained and/or concerned that working for lower quality funds could harm their reputation. If directors seek jobs at high quality funds and funds seek to hire high quality directors, then the hedge fund directorship market would result in positive assortative matching, similar to the market for marriages (Greenwood, Guner, Kocharkov, and Santos, 2014), or the market matching underwriters to firms issuing public equity (Fernando, Gatchev, and Spindt, 2005).

Hypothesis $\mathbf{2} \mathbf{b}$ We expect busier directors to match with higher quality funds in the labor market.

\subsection{Results}

We test these hypotheses in Table 5 with a director selection model that uses a conditional logit regression to estimate the probability a fund hires a specific director as a function of the interaction between fund and director characteristics. This approach is similar to the one employed in Kuhnen (2009) to estimate the likelihood a mutual fund adviser hires a specific sub-adviser from the set of all sub-adviser candidates. The unit of observation is the fund-director pair (directorship). For each director that is hired by a fund during our sample (2,616 unique hires), we select 100 random control directors from the universe of outside 
directors that served on any board in that period, but were not hired by the fund. The fixed effects in the conditional logit regression are at the fund-date level, which controls for fund and time characteristics involved in the hiring decision. Thus, the effects estimated in this approach are at the director and director-fund pair level. In each model, we include a measure of fund-specific human capital and control for the general reputational capital of the director using the number of advisers or number of funds the director work for. Previous Adviser Relationships is a count of the number of instances the director previously worked with the fund's adviser. Experience with Administrator (Experience with Other Service Providers) is an indicator variable equal to one if the director has experience with the fund's administrator (custodian, auditing firm, law firm, or prime broker), and zero otherwise. Director Portfolio Correlation is defined as the correlation of the fund's returns with the returns of the other fund's in the director's portfolio. The logic behind this variable is that funds operating similar strategies should have more correlated returns (Sun, Wang, and Zheng, 2012). Correlations are estimated on a rolling basis over the previous 36 months for both the treatment and control directors. Local Director is an indicator equal to one if the director resides in the same country as the fund's domicile.

In Model 1, we find a significant and positive relation between the human capital variables and the probability the director is hired by a fund. A director is 5.2 times more likely to be hired by a fund if they have previously worked for another one of the adviser's funds. Directors that have experience with the fund's administrator (other service providers), are 2.3 (1.2) times more likely to be hired, and a one standard deviation increase in Director Portfolio Correlation increases the chances the director is hired by 3.1 times. Finally, we see that a fund is 4.3 times more likely to hire a local director. Taken together, the results indicate that fund-specific human capital plays an important role in the labor market for hedge fund directors, suggesting that directors and funds match in such a way as to reduce the time constraints associated with performing the director's duties. 
To test our assortative matching hypothesis, we add interactions of fund characteristics with our measures of the reputational capital of the director (i.e., \# of Advisers or \# of Funds the director works for). Fund Return is the fund's trailing three year return. Fund Regulatory Violation equals one is the fund's adviser reports a regulatory action on its Form ADV. Note, because the fund is common to both the actual director and the 100 random control directors for each hiring event, the base effect of the fund characteristic has already been controlled for by the model's fixed effects. In Model 2, we find that \# of Advisers $\times$ Fund Return is positive and statistically significant (at the 10\% level). Thus, funds with higher past returns are more likely to hire directors who work for a larger number of advisers. In Model 3, we find that \# of Advisers $\times$ Fund Regulatory Violation is negative and significant. Funds with managers that have no history of regulatory violations hire directors who work for a greater number of advisers. We find similar results in Models 4 through 6 when we use \# of Funds instead of \# of Advisers. Collectively, these results suggest that higher quality funds are able to hire directors with better reputations, consistent with positive assortative matching.

\section{Evidence of Certification: Director Exits and Fund Flows}

Positive assortative matching is consistent with the idea that reputable independent directors act as a certification mechanism for high quality funds. If so, what happens when the director removes his certification from the fund? Once on the board, a director has an incentive to monitor the fund and influence management to behave appropriately. However, if he is unable to influence the fund against engaging in conduct that could tarnish his reputation, he has an incentive to leave the board. Given this incentive, the departure of an independent director from the board could be viewed as a loss of certification and cause investors to negatively update their opinion of fund quality (Fahlenbrach, Low, and Stulz, 2013). If the departure of an independent director is tantamount to a loss of certification, then we would expect to see their departures accompanied by outflows of investor capital. 
To test this prediction, in Table 6, we model the relation between independent director exits and fund flows in a regression framework. Again, we define a director to be Independent if he sits on the boards of funds managed by multiple advisers and the director is not conflicted by providing other services to the fund such as legal or audit work. The unit of observation is a fund-quarter. The dependent variable is the fund's quarterly, implied net flow. In each model, we control for observable fund characteristics that have been shown to affect flows, including lagged values of fund size, age, fees, share illiquidity, flows, performance, and volatility. We also include style, time, and jurisdiction fixed effects to control for unobservable heterogeneity that may explain fund flows. ${ }^{11}$ We cluster our standard errors at the fund level.

In Model 1 of Table 6, we find that when a fund loses and is unable to replace at least one independent director, on average the fund loses $4.7 \%$ of its capital. This effect is statistically significant and economically meaningful, given that the average quarterly flow in our sample is $-0.28 \%$. To control for any backfill bias, we remove the first 18 months of each fund's return history in Model 2 and our results are unchanged. In Model 3, we restrict the sample to those funds with more liquid redemption restrictions (notice periods of one quarter or less) so as to more clearly identify cases where investors could react to director departures in a timely manner. In these cases independent director exits are associated with a $6.8 \%$ outflow. 12 Another concern with our analysis is that directors and investors may be simultaneously leaving funds because of poor current performance. To address this issue, in Model 4 we drop funds in the bottom style-adjusted performance quintile for the current quarter. Our results are similar.

As we do not observe the cause of director turnover, some director exits are likely benign

\footnotetext{
${ }^{11}$ Past research has shown that fund flows and flow-performance relationship can vary across fund domicile (Cumming, Dai, and Johan, 2015a). In addition to including jurisdiction fixed effects, when we include interactions between jurisdiction dummies and past performance (untabulated), the results are unchanged.

${ }^{12}$ We also consider the possibility that a change in service provider, such as administrator or auditor, could confound the analysis. In unreported tests, we re-run Model 1 and exclude observations with any concurrent change in service providers. We find the results are qualitatively similar.
} 
(e.g. director retirement). In these cases, certification may not be lost if a fund can replace a lost independent director with another reputable director. In Model 5, Independent Exit w/ Replacement equals one if the fund replaces an independent director with another independent director, and zero otherwise. The coefficients on Independent Exit w/o Replacement and Independent Exit w/ Replacement are not additive, as we separately estimate the effect of director departure on flows based on whether the director is replaced. We find that flows are statistically insignificant surrounding independent director replacements. ${ }^{13}$ This suggests that the loss of an independent director sends a stronger negative signal if the fund does not (or cannot) replace the director.

If the value of a director's certification hinges on his reputation, then we would expect the magnitude of the investors' reaction to be positively related to the magnitude of the exiting director's reputational capital. In Model 6, we include exits of non-independent directors, i.e., directors that only work for the one adviser. Examining the loss of non-independent directors serves as a placebo test of whether investor withdrawals are associated with director departures in general, or whether investors distinguish the information content of departures based on the reputation of the director. The flow response to the loss of a non-independent director is approximately zero. In Model 7, we examine the magnitude of reputational capital lost by measuring the number of external adviser board seats held by the exiting independent director, EXIT $\times \#$ External Advisers. We find that even within the sample of independent director exits, investors react more negatively to the exits of independent directors that serve more external advisers. We find similar results in Model 8 when we proxy for reputational capital using the number of different external fund's a director works for.

Collectively, these results support the notion that a director's outside reputation is an important component of his ability to certify fund quality, as the market reacts more negatively

\footnotetext{
${ }^{13}$ In unreported tests, we separately examine whether the independent director was replaced from within the same directorship firm or with a director from another directorship firm. The results are similar.
} 
to the loss of certification from more reputable directors. An alternative explanation of our findings is that independent director exits are not a signal that investors use to update their priors about fund quality, but rather that the exit of independent directors may be related to some unobservable negative shock to the fund that directors and investors observe simultaneously, causing them both to leave the fund. However, this explanation does not contradict our main contention, which is that busier directors have more pronounced reputational incentives to exit the board when they perceive trouble at the fund, bolstering their ability to serve as a certification mechanism.

\section{Evidence of Monitoring: Fraud, Discretionary Liquidity Restrictions, and Risk Shifting}

\subsection{Fund Fraud}

Because they face limited oversight and disclosure rules, hedge funds are particularly susceptible to operational risks (Brown, Goetzmann, Liang, and Schwarz, 2008). Perhaps the most important role of directors is to monitor fund activities so as to ensure the fund is complying with the law and is not engaging in misconduct that could harm investors. Directors must approve many actions taken by the fund where there is opportunity to engage in misconduct, such as the valuation of illiquid assets, in-house trades with the investment adviser, and the certification of the accuracy of fund information. If independent directors play a governance role in hedge funds by providing external monitoring, we should expect to see a lower prevalence of fraud for funds with more reputable independent directors on their board. We test this proposition using administrative proceedings related to hedge fund fraud filed by the Securities and Exchange Commission.

To obtain hedge fund fraud data, we follow an approach similar to Dimmock and Gerken (2012) and search all SEC administrative proceedings that contain the terms "fraud" and 
"hedge fund" filed from January 2009 through November 2015. ${ }^{14}$ This process yields 181 filings. We read each filing and find 92 cases where a fund from our sample was involved in fraud. We combine related cases into a single event. For example, in one case the fund manager disproportionately allocated favorable trades to six client accounts (including ones in which the manager had a personal stake), earned additional fees based on the boost in its performance as a result, and misallocated fund assets to pay for part of a divorce settlement and for a personal timeshare in New York.

Because we care about when the fraud occurred (rather than when it was detected), we use the detail from the administrative proceedings to determine the time period when the SEC reports the fraud to have actually taken place. In doing so, we avoid potential bias caused by a correlation between detection and time variation in the predictive variables of interest. ${ }^{15}$ We then create an indicator variable Fraud, which is equal to one if the fund was engaged in a fraud in a particular quarter and zero otherwise. In our sample, a fraud is ongoing in $1.2 \%$ of fund-quarters. ${ }^{16}$

Table 7 reports results from a logit regression predicting Fraud in period $t+1$ as a function of board variables and other fund characteristics observed in period $t$. The unit of observation is a fund-quarter, and we use the full sample of funds with non-missing data. The number of observations in Table 7 is much larger than in our previous tables because we do not require any variables from the commercial databases. ${ }^{17}$ In each model our variable of

\footnotetext{
${ }^{14}$ We look for detected case of fraud through the end of November 2015 as fraud may occur for several years before it is detected and reported in the SEC administrative proceedings.

${ }^{15}$ A related concern shared with many archival studies of misconduct is that we only observe detected events. Fund characteristics that decreases the probability of detection increases the incentive for fraud. In general, this relation biases against finding significant results in a predictive model, as characteristics associated with a higher rate of fraud will also be associated with a lower detection rate.

${ }^{16}$ The observed rate of fraud is similar to other studies of investment managers (e.g. Dimmock and Gerken, 2012) as well as other types of corporate fraud (e.g. Karpoff, Lee, and Martin, 2008).

${ }^{17} \mathrm{As}$ we report below, funds that voluntarily report to commercial databases are much less likely to commit fraud, creating a potential selection bias. In an untabulated result, we also estimate the model using only the funds that report to a commercial database and find qualitatively similar and significant results for our measures of board independence.
} 
interest is a measure of board reputation/independence. In addition, we control for three measures related to board diversity: board age, whether the board has a female director, and the overlap in past positions held by the directors, as past studies find that increased diversity can reduce the incidence of fraud (e.g., see Cumming, Leung, and Rui (2015b)). We also control for fund size, adviser size, minimum investment, institutional clientele, and whether the fund reports to commercial hedge fund databases. Standard errors are clustered at the fund-level.

In Model 1, our measure of board reputation/independence is the indicator variable Has Independent, which equals one if there is at least one independent director on the board, and zero otherwise. The coefficient on Has Independent is negative and significant at the less than $1 \%$ level. The result implies that funds with independent directors are $84 \%$ less likely to engage in fraud. In Models 2 and 3 we measure board reputation/independence as the normalized sum of board engagements held by the outside directors of the fund that are external to the fund's adviser. We use the number of external advisers, \# External Advisers, in Model 2 and the number of external funds, \# External Funds, in Model 3. Consistent with Model 1, both these models provide evidence that greater board reputation/independence is related to a much lower likely of future fraudulent behavior. We note that we also find evidence that more diverse boards are less likely to commit fraud, consistent with past literature. Specifically, we find that funds with a female director are significantly less likely to engage in fraud and funds whose directors have worked with each other on more past engagements (and thus are potentially more prone to groupthink) are more likely to commit fraud.

In unreported analysis on those funds for which we have detailed service provider data, we also control for other governance metrics that were shown in Brown et al. (2012) to be related to hedge fund operational risk: whether the fund had a Big 4 auditor, valued its assets internally, and switched its administrator. Our key results still hold. Further, we also 
run our analyses including individual service provider fixed effects and find similar results, indicating the effect of board independence on fraud cannot simply be explained solely by cross-sectional differences in the quality of other fund service providers.

As detected fraud is jointly determined by the true fraud rate and detection rate, we need to exercise care in attributing differences in the observed fraud rates. We address this in two ways. First, we identify when fraud occurred and the dependent variable is measured during the occurrence of fraud in a given year, even if the fraud is not detected until years later. Second, we examine the duration of the fraud as a proxy for detection rate. The average duration of the fraud is 14 quarters for funds with independent directors, and 17 quarters for those without. The shorter fraud duration for funds with independent boards is inconsistent with the idea that these funds have a lower fraud detection rate. To confirm the predictive validity of our models, we also perform K-fold cross-validation tests and find

consistent predictive power from our measures of board independence. ${ }^{18} \mathrm{In}$ sum, the presence of reputable, independent directors is strongly related to lower fraud risk.

\subsection{Discretionary Liquidity Restrictions}

During the recent financial crisis, many hedge fund managers used their discretion to restrict investor liquidity through the use of gates or side pockets. ${ }^{19}$ The use of these discretionary liquidity restrictions (DLRs) by fund managers is controversial because, while DLRs can protect investors by helping funds avoid costly fire sales, DLRs could be abused by managers who restrict withdrawals in order to preserve fund capital in the face of poor expected performance. Because the board has to approve the manager's decision to establish a DLR, they provide an interesting laboratory to test the monitoring efficacy of independent hedge fund directors. Specifically, we test whether there is an association between a fund's

\footnotetext{
${ }^{18}$ See Dimmock and Gerken (2012) for a discussion of the technique in this setting. ${ }^{19}$ See Aiken, Clifford, and Ellis (2015) for details of these discretionary liquidity restrictions.
} 
post-DLR performance and its board structure. If independent directors are better monitors they should be able to mitigate DLR abuses, meaning that the post-DLR performance should be higher for funds with independent boards than for funds with non-independent boards.

We begin with the sample of DLR funds used in Aiken, Clifford, and Ellis (2015), and collect Form D filings for each fund in order to obtain its board structure. The majority of DLRs were initiated between 2007-2009 which was before funds filed their Form D in electronic format. Prior to electronic filing, Form D's were kept on the SEC website in the format of scanned paper copies (sometimes containing hand-written responses), requiring manual encoding of each fund filing. Because of the cost of obtaining this data, we only obtain board structures for the DLR sample of funds, which means we cannot ascertain the number of other directorships held by the director. However, we can ascertain whether the director is an outsider or an insider, and we use this classification as a proxy for board independence. ${ }^{20}$ Our sample includes 230 DLR funds, 52 of which have an independent director on their board. The presence of independent directors in the DLR sample (22.6\%) is far lower than the full-sample average we use in our main analysis (79.2\%), suggesting that funds with independent directors were less likely to establish DLRs than funds with inside-only boards. ${ }^{21}$

In Figure 1 we present the compound quarterly performance of DLR funds stratified by board structure along with the performance of the hedge fund index in event time surrounding the DLR initiation quarter. We see that both funds with and without independent directors significantly underperform the hedge fund index in the quarters leading up to the DLR, suggesting that both types of funds enact DLRs in response to poor performance. Remember that the efficient rationale for imposing DLRs is to avoid being forced to sell temporarily

${ }^{20}$ When we examine the sample of data where we can obtain the directors' other employment data, this proxy procedure correctly classifies independent boards $88 \%$ of the time.

${ }^{21}$ We note, however, that the differences in data collection procedures and sample timing between the DLR and full sample could affect these inferences. 
undervalued assets at fire-sale prices. Thus, enacting DLRs in response to poor performance is not evidence of managerial malfeasance. However, the efficient rationale also predicts that the fund should realize a rebound in performance subsequent to enacting the DLR, as its undervalued assets return to fair value as markets stabilize.

When we examine the two years following the DLR, it is clear that funds with inside-only boards do not experience a rebound in performance, as their cumulative performance is essentially flat over that period. In contrast, funds with independent directors experience a pronounced rebound in performance and eclipse their pre-DLR asset values by the end of the fourth quarter. Moreover, the independent board sample significantly outperforms the inside-only sample by $2.02 \%$ per quarter $(t$-stat=3.73) over the two years following the DLR. This pattern is striking, as it suggests that the performance pattern of funds with an independent board more closely resembles how it should look if the funds enacted DLRs to protect investor interests. This evidence suggests independent directors play an important role in hedge fund governance by monitoring the manager's discretionary choices in order to mitigate conflicts of interest with investors.

\subsection{Risk Shifting}

Another potential agency problem is performance-based risk-shifting, which is the idea that when funds face convex incentives based on their calendar year-end performance, those with poor performance in the first half of the year may have an incentive to increase risk in the second half of the year in order to "catch-up" to their peers or to meet certain pre-defined performance thresholds. This type of strategic risk-shifting has been documented for both mutual funds (Brown, Harlow, and Starks, 1996), and hedge funds (Aragon and Nanda, 2012), and there is evidence that risk-shifting directly harms investor interests (Huang, Sialm, and Zhang, 2011). In our sample, more than $90 \%$ of hedge funds have a performance-based incentive fee that is subject to a highwater mark provision (HWM), meaning the fund only 
earns an incentive fee if its performance is high enough to eclipse the fund's HWM by the end of the calendar year. This asymmetric compensation structure directly creates convex incentives that could induce poor performers at mid-year to increase risk in the second half of the year in order to increase the probability they earn a performance fee. In this section, we test whether funds with more reputable, independent directors are less likely to engage in this type of risk shifting.

Our methodological setup is similar to Aragon and Nanda (2012). We form an annual panel of hedge funds and regress changes in hedge fund risk on mid-year fund performance, measures of board independence/reputation, and other fund controls. The dependent variable, $\Delta R i s k$, is the difference in the standard deviations of the fund's monthly returns between the first half and second half of the calendar year. BOARD refers to one of our three board reputation proxies: Has Independent, \# External Board Seats, and \# External Advisers. We follow Aragon and Nanda (2012) and measure mid-year performance $\left(\right.$ Perf $\left._{\text {June }}\right)$ as the fractional rank (within style) of the fund's percentage distance to its HWM as of the end of June. We use the within-style ranking of this measure to account for the fact that funds may also care about their performance relative to their peers, though we find similar results with the unadjusted measure. We also include several control variables, including controls for lagged risk and changes in fund autocorrelation to control for mean reversion, as well as fund size, flows, age, minimum investment, share restrictions, leverage, and fees. In each model, the variable of interest is the coefficient on the interaction $B O A R D \times \operatorname{Perf}_{\text {June }}$, as this tests whether the presence of independent/reputable directors helps to curtail a fund's propensity to increase risk following poor performance.

The results of these regressions are reported in Table 8. The coefficient on BOARD is negative in each model, meaning that funds with reputable independent directors engage in less risk shifting unconditional on performance. Consistent with the risk-shifting literature, the coefficient on $\operatorname{Perf}_{\text {June }}$ is negative in each model, meaning that funds tend to increase 
risk in the second half of the year following poor performance in the first half of the year.

Overall, we find some evidence that funds with more reputable independent directors on the board engage in less performance-based risk shifting. Specifically, the coefficient on the interaction $B O A R D \times \operatorname{Perf}_{\text {June }}$ is positive and significant at the $1 \%$ level for the board measures \# External Board Seats and \# External Advisers. The coefficient estimates indicate that a one standard deviation in \# External Board Seats or \# External Advisers reduces risk shifting by roughly $37 \%$. Interestingly, the coefficient on the interaction is insignificant when we use the Has Independent measure, suggesting that it is the independent directors with greater reputational capital that are able to curtail performance-based risk shifting. Collectively, we view this as additional evidence that suggests reputable independent directors are able to constrain hedge fund agency problems.

\section{Discussion of Alternative Hypothesis}

Thus far, we have interpreted our results as suggesting that director labor market incentives create a virtuous cycle of job accumulation and director incentive alignment: good directors are rewarded in the director labor market with more jobs, which increases their reputational capital and independence from management, which increases their incentives and ability to be good monitors, making them even more attractive in the director labor market. Absent exogenous variation in director certification, however, we acknowledge that it is difficult to rule out all possible alternative hypotheses. ${ }^{22}$

One plausible alternative explanation for our results is that directors become busy by agreeing to serve as cronies of management, and their noted willingness to sign off on management's wishes makes them more attractive in the labor market. We take seriously this "rubber-stamp" hypothesis and, for reasons we discuss below, find it to be inconsistent

\footnotetext{
${ }^{22}$ For example, director deaths are far too infrequent in our sample for any meaningful empirical analysis, and no significant regulatory changes regarding directors were implemented.
} 
with the entirety of our evidence.

First, we note that given the lack of regulation as to a board's composition, a less costly solution for the fund would be to appoint two internal candidates to the board to rubber-stamp the manager's decisions. Thus, this rubber-stamping equilibrium assumes that investors demand external directors serve on the board, but are naive about their role.

Second, the relation between director busyness and the likelihood of being hired by a fund is concave and flattens when directors are very busy, consistent with directors running into capacity cost issues when handling a heavy workload. Rubber-stamps should have an ever increasing, maybe even convex relation, as busy rubber stamps would be in high demand and would not face capacity costs when holding a token board seat.

Third, busier directors are more likely to match with better performing funds, consistent with positive assortative matching on fund and director quality. Rubber-stamps should be more equally sought after by poor quality funds, and one might expect that rubber-stamps would be more likely to work for poor performing funds that have not been properly monitored by the board. ${ }^{23}$

Fourth, busy directors are associated with a lower incidence of fund fraud and investors withdraw more money from the fund when busier directors exit. It is unlikely that the departure of a rubber-stamp director should signal that anything is wrong with the fund given that the management can always replace the departing director with an equally amenable inside director.

Finally, in untabulated analysis we repeat our tests and proxy for director reputation with External Director Return, which measures the average performance of the other funds the director works for (external to the "treated" adviser of the reference fund) over the past

\footnotetext{
${ }^{23}$ In untabulated analysis, we find the relation between future performance and board busyness is positive, though not significant. This contrasts with the view that busy directors would be harmful for firm performance.
} 
36 months. This measure is not mechanically related to the number of funds the director works for, yet we find statistically significant results that are consistent with our busyness measures, which helps corroborate the assertion that busyness is a proxy for a high-quality reputation rather than a crony reputation.

\section{Conclusion}

Following the recent wave of scandals and failures in the hedge fund industry, considerable debate has emerged as to how hedge funds should be governed. Despite receiving considerable scrutiny by practitioners and the media, the hedge fund's board of directors has garnered scant attention in the academic literature. This paper serves as a first step toward filling this gap. Hedge fund directors have fiduciary duties to protect investor interests by monitoring hedge fund managers, yet they are hired by the very managers they are meant to monitor. Thus, hedge directors could be co-opted by fund management in a way that is much stronger than the way in which a corporate director might be co-opted by the CEO. Corporate directors may be co-opted because the CEO has informal bargaining power with the board and influence over director selection decisions (Hermalin and Weisbach, 1998). However, common stockholders still have ultimate control over board composition through their voting power. In contrast, hedge fund investors cannot vote for their preferred directors and are left to vote with their feet. Our collective findings suggest that several unique institutional features have emerged in the market for hedge fund directors which serve to ameliorate this inherent conflict.

Most hedge funds voluntarily elect outside directors to their board, and the majority of these outside directorships are held by a select group of professionals that serve on dozens of boards at once. Many of these professional directors are members of directorships firms which appear to be organized similarly to large law or accounting firms. Our results cast considerable doubt on the claim that these institutional features are symptoms of the irrelevancy of hedge 
fund boards. Rather, we contend that these features emerged to make boards relevant, and can in part be explained by the market forces of reputational bonding and certification. Funds desire outside certification to attract investors, and professional directors put their own and their firm's reputational capital on the line to make that certification credible. Though the director may be very busy, the upshot is that investors know his prosperity does not depend on pleasing any particular manager that hired him. Many (e.g., Romano, 2005) have raised significant concerns about establishing true director independence, given that many "independent" directors have a personal interest in retaining their friendly relationship with management. We posit that by serving many masters at once, busy directors may be able to more closely represent investor interests in the true spirit of independence. 
Table A.1

\section{Variable Definitions}

The following table defines each of the variables in the paper and provides its source. Our data come from five unique databases: Form D (SEC), Form ADV (SEC), the union of the five largest commercial hedge fund databases (LipperTass, HFR, BarclayHedge, Eureka Hedge, and Morningstar), FundGov, and LinkedIn.

\begin{tabular}{|c|c|c|}
\hline Variable & Definition & Source \\
\hline \# Directors & Count variable for the number of directors on the board & Form D \\
\hline \# Insider & $\begin{array}{l}\text { Count variable for the number of inside (i.e. employed by } \\
\text { hedge fund's investment adviser) directors on the board }\end{array}$ & Form D \\
\hline \# of Advisers & $\begin{array}{l}\text { Number of unique advisers among fund boards on which the } \\
\text { the director currently serves }\end{array}$ & Form D \\
\hline \# of External Advisers & $\begin{array}{l}\text { Number of unique advisers among fund boards on which the } \\
\text { the director currently serves, external to the affiliated adviser }\end{array}$ & Form D \\
\hline \# of External Funds & $\begin{array}{l}\text { Number of unique fund boards on which the the director } \\
\text { currently serves, external to the affiliated adviser }\end{array}$ & Form D \\
\hline \# of Funds & $\begin{array}{l}\text { Number of unique fund boards on which the the director } \\
\text { currently serves }\end{array}$ & Form D \\
\hline \# Outsider & $\begin{array}{l}\text { Count variable for the number of outside (i.e. not employed } \\
\text { by hedge fund's investment adviser) directors on the board }\end{array}$ & Form D \\
\hline Director Portfolio Correlation & $\begin{array}{l}\text { 36-month correlation of the fund's returns with the returns } \\
\text { of the external funds in the director's portfolio }\end{array}$ & Commercial Databases \\
\hline Director Return & $\begin{array}{l}\text { 36-month equal-weighted return of the portfolio of hedge } \\
\text { funds for which the director serves on the board }\end{array}$ & Commercial Databases \\
\hline Directorship Firm & $\begin{array}{l}\text { Indicator variable equal to one if the director is employed by } \\
\text { a professional directorship firm, and zero otherwise }\end{array}$ & Form D \\
\hline Directorship Firm's \# of Funds & $\begin{array}{l}\text { Count variable based on the number of directorships held by } \\
\text { the directors in the directorship firm }\end{array}$ & Form D \\
\hline Experience with Administrator & $\begin{array}{l}\text { Indicator variable equal to one if the director had previously } \\
\text { worked for a fund that uses the same administrator as the } \\
\text { hiring fund, and zero otherwise }\end{array}$ & Commercial Databases \\
\hline Experience with Adviser & $\begin{array}{l}\text { Count variable of the number of times the director had } \\
\text { previously worked for a fund run by the hedge fund adviser }\end{array}$ & Form D \\
\hline
\end{tabular}


Experience with Other Service Providers

Flow

Fund Age

Fund Regulatory Violation

Fund Size

Incentive Fee

Independent

Management Fee

¿ Minimum Investment

Past Failures

Performance Rank

Reports to a Database

Share Liquidity

Standard Deviation

Teammate
Indicator variable equal to one if the director had previously worked for a fund that uses the same law firm, accounting firm, prime broker, or custodian as the hiring fund, and zero otherwise

Fund's implied, quarterly net flow

Age of the fund based on the funds date of initial sale

Indicator variable equal to one if the fund's adviser reports a regulatory action, and zero otherwise

Assets under management for the fund

Annual performance-based fee charged by the fund

Indicator variable equal to one if the fund has an independent director (i.e. an outside director employed by multiple advisers that is not conflicted by providing other services to the fund such as legal or audit work.)

Annual management fee charged by the fund

Fund's stated minimum investment to join the fund

Count variable of the number of funds the director sat on a fund that failed

Rank of the fund's return over the previous 12 months Indicator variable equal to one if the fund reports to a commercial database in quarter $t$, and zero otherwise

Indicator equal to one if the fund's share liquidity is above median. We collapse share liquidity to one factor by taking the first principal component from the fund's lockup, redemption notice period, and redemption frequency.

Standard deviation of the fund's monthly returns over the previous 12 months

Indicator variable equal to one if the director simultaneously serves on a board with another director from the same Directorship Firm, and zero otherwise
Commercial Databases

Commercial Databases

Form D

Form ADV

Form D

Commercial Databases

Form D

Commercial Databases

Form D

Commercial Databases

Commercial Databases Commercial Databases

Commercial Databases

Commercial Databases

Form D 
Director Age

Female

Top 100 School

CFA

Grad School

Fund Experience

\section{CEO Experience}

PE Experience

Law Experience

Accounting Experience

Local Director
Age of director in year $t$

FundGov

Indicator variable equal to one if the director is female, FundGov and zero otherwise

Indicator variable equal to one if the director's undergrad- LinkedIn uate institution was ranked in the top 100 universities by QS World University Rankings, and zero otherwise

Indicator variable equal to one if the director is a char- LinkedIn tered financial analyst, and zero otherwise

Indicator variable equal to one if the director has an LinkedIn advanced degree, and zero otherwise

Indicator variable equal to one if the director has profes- FundGov sional work experience in the investment management industry, and zero otherwise

Indicator variable equal to one if the director has profes- FundGov sional work experience as a CEO, and zero otherwise

Indicator variable equal to one if the director has pro- FundGov fessional work experience in the private equity industry, and zero otherwise

Indicator variable equal to one if the director has profes- FundGov sional work experience as a lawyer, and zero otherwise

Indicator variable equal to one if the director has pro- FundGov fessional work experience as an accountant, and zero otherwise

Indicator variable equal to one if the director's country FundGov of residence is the same as the domicile of the fund, and zero otherwise 


\section{References}

Agarwal, Vikas, Naveen D. Daniel, Narayan Y. Naik. 2009. Role of managerial incentives and discretion in hedge fund performance. Journal of Finance, 64 2221-2256.

Agarwal, Vikas, Naveen D. Daniel, Narayan Y. Naik. 2011. Do hedge funds manage their reported returns? Review of Financial Studies, 24 3281-3320.

Agarwal, Vikas, Vyacheslav Fos, Wei Jiang. 2013. Inferring reporting biases in hedge fund databases from hedge fund equity holdings. Management Science, 59 1271-1289.

Aiken, Adam L., Christopher P. Clifford, Jesse A. Ellis. 2013. Out of the dark: Hedge fund reporting biases and commercial databases. Review of Financial Studies, 26 208-243.

Aiken, Adam L., Christopher P. Clifford, Jesse A. Ellis. 2015. Hedge funds and discretionary liquidity restrictions. Journal of Financial Economics, 116 197-218.

Aragon, George, Vikram Nanda. 2012. Tournament behavior in hedge funds: High-water marks, fund liquidation, and managerial stake. Review of Financial Studies, 25 937-974.

Aragon, George O., Bing Liang, Hyuna Park. 2014. Onshore and offshore hedge funds: Are they twins? Management Science, 60 74-91.

Bollen, Nicolas P.B., Veronika K. Pool. 2009. Do hedge fund managers misreport returns? Evidence from the pooled distribution. Journal of Finance, 64 2257-2288.

Bollen, Nicolas P.B., Veronika K. Pool. 2012. Suspicious patterns in hedge fund returns and the risk of fraud. Review of Financial Studies, 25 2673-2702.

Brown, Keith C., W. V. Harlow, Laura T. Starks. 1996. Of tournaments and temptations: An analysis of managerial incentives in the mutual fund industry. Journal of Finance, $\mathbf{5 1}$ 85-110.

Brown, Stephen, William Goetzmann, Bing Liang, Christopher Schwarz. 2008. Mandatory disclosure and operational risk: Evidence from hedge fund registration. Journal of Finance, $632785-2815$.

Brown, Stephen, William Goetzmann, Bing Liang, Christopher Schwarz. 2012. Trust and delegation. Journal of Financial Economics, 103 221-234.

Carne Global Financial Services. 2011. Corporate governance in hedge funds: Investor survey 2011.

Cassar, Gavin, Joesph Gerakos. 2010. Determinants of hedge fund internal controls and fees. Accounting Review, 85 1887-1919.

Coles, Jeffrey L., Naveen D. Daniel, Lalitha Naveen. 2014. Co-opted boards. Review of Financial Studies, 27 1751-1796. 
Cumming, Douglas. 2006. The determinants of venture capital portfolio size. Journal of Business, 79 1083-1126.

Cumming, Douglas, Na Dai. 2010. Hedge fund regulation and misreporting returns. European Financial Management, 16 829-857.

Cumming, Douglas, Na Dai, Sofia A. Johan. 2013. Hedge Fund Structure, Regulation, and Performance around the World. Oxford University Press.

Cumming, Douglas, Na Dai, Sofia A. Johan. 2015a. Are hedge funds domiciled in Delaware different? Journal of Corporate Finance, 35 232-246.

Cumming, Douglas, T.Y. Leung, Oliver Rui. 2015b. Gender diversity and securities fraud. Academy of Management Journal, 58 1572-1593.

Cumming, Douglas, Uwe Walz. 2010. Private equity returns and disclosure around the world. Journal of International Business Studies, 41(4) 727-754.

Dass, Nishant, Omesh Kini, Vikram Nanda, Bunyamin Onal, Jun Wang. 2014. Board expertise: Do directors from related industries help bridge the information gap? Review of Financial Studies, 27 1533-1592.

Denis, David J., Diane K. Denis, Mark D. Walker. 2015. CEO assessment and the structure of newly formed boards. Review of Financial Studies, 28 3338-3366.

Dimmock, Stephen G., William C. Gerken. 2012. Predicting fraud by investment managers. Journal of Financial Economics, 105 153-173.

Dimmock, Stephen G., William C. Gerken. 2016. Regulatory oversight and return misreporting by hedge funds. Review of Finance, 20 795-821.

Fahlenbrach, Rüdiger, Angie Low, René Stulz. 2013. The dark side of outside directors: Do they quit ahead of trouble? Fisher College of Business Working Paper.

Fama, Eugene F., Michael C. Jensen. 1983. Separation of ownership and control. Journal of Law and Economics, 26 301-325.

Fernando, Chitru S., Vladimir A. Gatchev, Paul A. Spindt. 2005. Wanna dance? How firms and underwriters choose each other. Journal of Finance, 60 2437-2469.

Fich, Eliezer M., Anil Shivdasani. 2006. Are busy boards effect monitors? Journal of Finance, $61689-724$.

Field, Laura, Michelle Lowry, Anahit Mkrtchyan. 2013. Are busy boards detrimental? Journal of Financial Economics, 109 63-82.

Greenwood, Jeremy, Nezih Guner, Georgi Kocharkov, Cezar Santos. 2014. Marry your like: Assortative mating and income inequality. American Economic Review, 104 348-353. 
Hermalin, Benjamin, Michael Weisbach. 1998. Endogenously chosen boards of directors and their monitoring of the CEO. American Economic Review, 88 96-118.

Huang, Jennifer, Clemens Sialm, Hanjiang Zhang. 2011. Risk shifting and mutual fund performance. Review of Financial Studies, 24 2575-2616.

Ivanov, Vlad, Scott Bauguess. 2012. Capital raising in the U.S.: The significance of unregistered offerings using the Regulation D exemption. Securities and Exchange Commission Memorandum.

Kanniainen, Vesa, Christian Keuschnigg. 2003. The optimal portfolio of start-up firms in venture capital finance. Journal of Corporate Finance, 9 521-534.

Kaplan, Steven N., David Reishus. 1990. Outside directorships and corporate performance. Journal of Financial Economics, 27 389-410.

Karpoff, Jonathan, D. Lee, Gerald Martin. 2008. The cost to firms of cooking the books. Journal of Financial and Quantitative Analysis, 43 581-612.

Knyazeva, Anzhela, Diana Knyazeva, Ronald Masulis. 2013. The supply of corporate directors and board independence. Review of Financial Studies, 26 1561-1605.

Kuhnen, Camelia M. 2009. Business networks, corporate governance, and contracting in the mutual fund industry. Journal of Finance, 64 2185-2220.

Masulis, Ronald W., Shawn Mobbs. 2011. Are all inside directors the same? Evidence from the external directorship market. Journal of Finance, 66 823-872.

Ozik, Gideon, Ronnie Sadka. 2014. Skin in the game versus skimming the game: Governance, share restrictions, and insider flow. Journal of Financial and Quantitative Analysis forthcoming.

Patton, Andrew J., Tarun Ramadorai, Michael Streatfield. 2015. Change you can believe in? Hedge fund data revisions. Journal of Finance, 70 963-999.

Romano, Roberta. 2005. The Sarbanes-Oxley Act and the making of quack corporate governance. Yale Law School Working Paper.

SEC Division of Investment Management. 2015. Private funds statistics.

Sun, Zheng, Ashley Wang, Lu Zheng. 2012. The road less traveled: Strategy distinctiveness and hedge fund performance. Review of Financial Studies, 25 96-143.

Tirole, Jean. 1996. A theory of collective reputations (with applications to the persistence of corruption and to firm quality). Review of Economic Studies, 63 1-22.

Tower Watson Survey. 2013. Executive compensation bulletin: Fortune 500 outside director pay shows modest growth, emphasis on cash. 
Vafeas, Nikos. 1999. The nature of board nominating committees and their role in corporate governance. Journal of Business Finance and Accounting, 26 199-225.

Yermack, David. 2004. Remuneration, retention, and reputation incentives for outside directors. Journal of Finance, 59 2281-2308. 


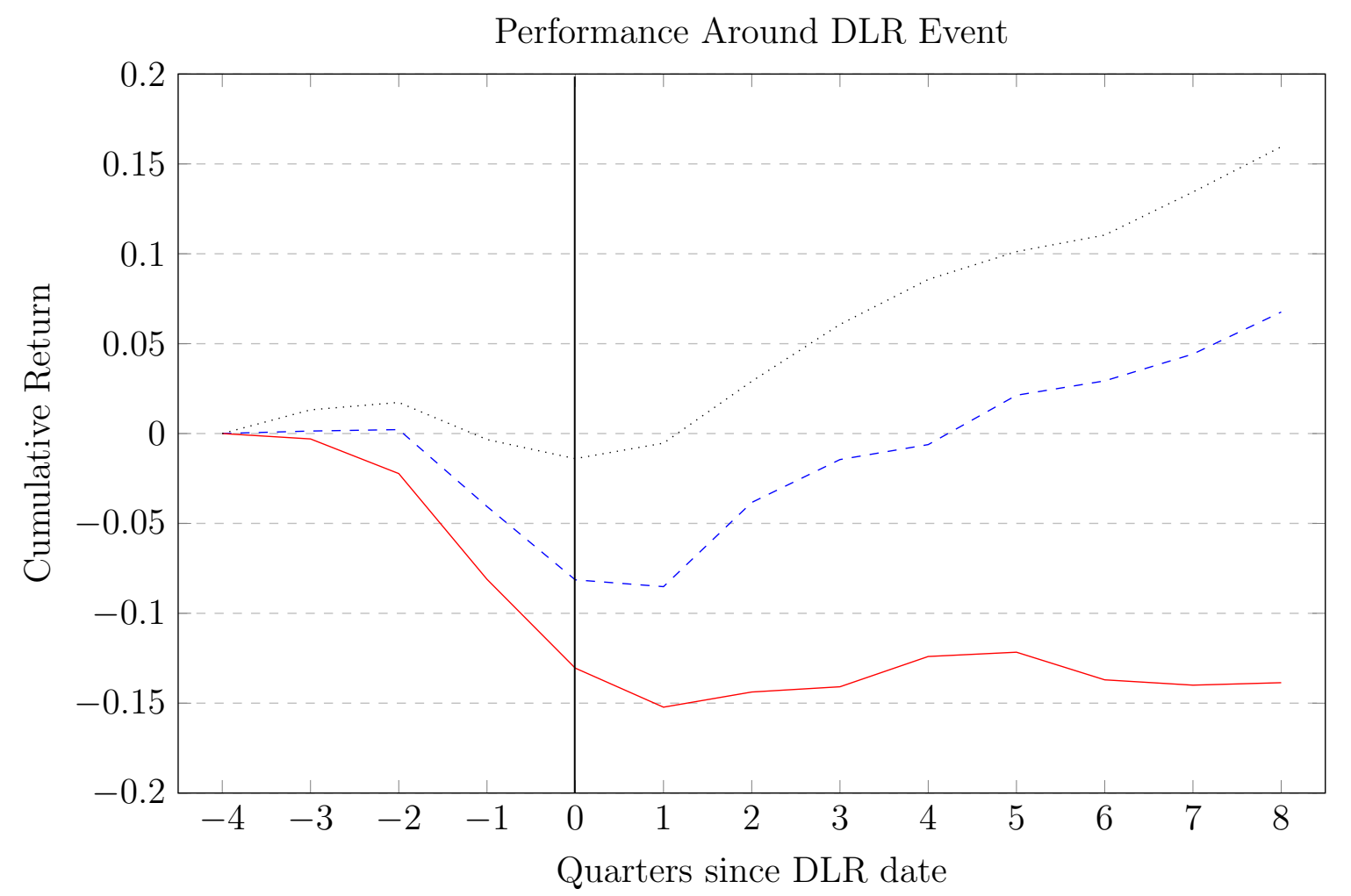

Fig. 1

Performance around Discretionary Liquidity Restriction Event

The figure presents the average cumulative returns for three separate portfolios, where quarter 0 is the DLR event quarter. Has Independence represents the returns from the set of funds that have at least one independent director on the board. No Independence represents the set of funds that have no independent directors on the board. Index represents returns from an equal-weighted quarterly hedge fund index from the union of five commercial databases (Lipper TASS, HFR, BarclayHedge, Morningstar, and Eurekahedge). 


\section{Table 1}

\section{Hedge Fund Board Structure}

We present summary statistics for hedge fund board structures during our sample period of 20092013. The unit of observation is a hedge fund-quarter. In Panel A, we report the distribution of board structures. \# Directors is a count variable for the number of directors on the board. \# Insiders is a count variable for the number of inside directors on the board. \# Outsiders is a count variable for the number of outside directors on the board. Any Outsider is an indicator variable equal to one if the board has at least one Outsider, and zero otherwise. In Panel B, we tabulate the frequency of board structures by number of inside and outside directors. In Panel C, we report the $\%$ of funds and the average number of directors/outside directors by the most common hedge fund domiciles in our sample.

Panel A: Board Structure

\begin{tabular}{ccccccc}
\hline & Mean & 10 th & 25 th & Median & 75 th & 90 th \\
\hline \# Directors & 3.1 & 2.0 & 2.0 & 3.0 & 3.0 & 5.0 \\
\# Insider & 1.3 & 0.0 & 0.0 & 1.0 & 2.0 & 3.0 \\
\# Outsider & 1.8 & 0.0 & 1.0 & 2.0 & 2.0 & 3.0 \\
Any Outsider & $79.2 \%$ & $0.0 \%$ & $100.0 \%$ & $100.0 \%$ & $100.0 \%$ & $100.0 \%$ \\
\hline
\end{tabular}

Panel B: Distribution of Board Structures

\begin{tabular}{ccccccc}
\hline & \multicolumn{7}{c}{ Inside Directors } \\
\hline Outside Directors & 0 & 1 & 2 & $3+$ & Total \\
\hline 0 & $0.0 \%$ & $5.6 \%$ & $8.1 \%$ & $7.1 \%$ & $20.8 \%$ \\
1 & $0.7 \%$ & $4.4 \%$ & $4.5 \%$ & $1.7 \%$ & $11.3 \%$ \\
2 & $14.7 \%$ & $25.5 \%$ & $2.6 \%$ & $2.9 \%$ & $45.6 \%$ \\
$3+$ & $13.3 \%$ & $3.9 \%$ & $3.2 \%$ & $1.9 \%$ & $22.3 \%$ \\
Total & $28.7 \%$ & $39.4 \%$ & $18.4 \%$ & $13.5 \%$ & $100.0 \%$ \\
\hline
\end{tabular}

Panel C: Hedge Fund Domicile

\begin{tabular}{cccc}
\hline Domicile & \% of Funds & Mean \# Directors & Mean \# Outsiders \\
\hline Cayman Islands & $79.6 \%$ & 2.9 & 1.7 \\
British Virgin Islands (BVI) & $7.8 \%$ & 3.4 & 1.6 \\
Bermuda & $4.0 \%$ & 3.6 & 2.0 \\
Other & $8.7 \%$ & 4.7 & 2.9 \\
\hline
\end{tabular}




\section{Table 2}

\section{Director Summary Statistics}

We present summary statistics for hedge fund directors during our sample period of 2009-2013. In Panel A, we separately present statistics for the \# of funds and the \# of advisers the outside director concurrently serves on at the director level and directorship level. At the Director Level, the unit of observation is from the director's perspective, namely an outside director-quarter. At the Directorship Level, the unit of observation is constructed from the fund's perspective, namely an outside board seat-quarter. In Panel B, we stratify our sample based on the director's workload across funds and director independence. We define a director to be independent if they sit on the boards of funds managed by multiple adviser and have no other business relationship with the fund. We report the proportion of outside directors and outside board seats for each strata. Further, we report whether a director was employed by a Directorship Firm and whether the director simultaneously serves on the board with a director from the same firm, Teammate. In Panel C, we repeat this approach to examine the distribution of service providers each strata of directors work with. In Panel D, we report director residency. In Panel E, we report biographic data for a sample of outside directors available from the data provider LinkedIn. 
Panel A: Director Residency

\begin{tabular}{cccccc}
\hline U.S. & Cayman Islands & U.K. & Other & Bermuda & BVI \\
\hline $27.8 \%$ & $16.0 \%$ & $8.4 \%$ & $6.7 \%$ & $6.7 \%$ & $1.5 \%$ \\
\hline \multirow{2}{*}{ Panel B: Director Workload } & & & & \\
\hline \multicolumn{7}{c}{ Director Level } & \# of Funds & Mean & 25 th & Median & 75 th \\
& \# of Advisers & 3.5 & 1.0 & 2.0 & 5.0 \\
& \# of Funds & 41.0 & 6.0 & 22.0 & 53.0 \\
\hline Directorship Level & \# of Advisers & 22.7 & 2.0 & 10.0 & 26.0 \\
\hline
\end{tabular}

Panel C: Director Characteristics - by Workload

\begin{tabular}{ccc}
\hline & $\%$ of Directors & $\%$ of Board Seats \\
\hline$[1-3]$ Funds & $67.6 \%$ & $17.9 \%$ \\
{$[4-20]$ Funds } & $24.8 \%$ & $30.7 \%$ \\
{$[21+]$ Funds } & $7.5 \%$ & $51.4 \%$ \\
\hline
\end{tabular}

Panel D: Director Bio - LinkedIn

Experience

\begin{tabular}{ccccc}
\hline Fund Management & Accounting & Law & CEO & Private Equity \\
\hline $39.1 \%$ & $8.5 \%$ & $8.2 \%$ & $3.5 \%$ & $2.9 \%$ \\
& & & & \\
\hline Age & Female & Top 100 School & CFA & Grad School \\
\hline 46.1 & $6.6 \%$ & $6.9 \%$ & $2.1 \%$ & $4.9 \%$ \\
\hline
\end{tabular}

Panel E: Directorship Firms - by Workload

\begin{tabular}{ccc}
\hline & Directorship Firm & Teammate \\
\hline$[1-3]$ Funds & $19.8 \%$ & $7.0 \%$ \\
{$[4-20]$ Funds } & $53.9 \%$ & $21.1 \%$ \\
{$[21+]$ Funds } & $81.1 \%$ & $42.4 \%$ \\
\hline
\end{tabular}




\section{Table 3}

\section{Director Level Hiring Determinants}

We use a logit model to predict the probability that a hedge fund director is hired in the subsequent quarter. The unit of observation is a director-quarter from the sample of outside hedge fund directors. All independent variables are defined in Table A.1. We include time fixed effects and cluster our standard errors at the director level. ${ }^{* * *}, * *$, and * represent statistical significance at the $1 \%, 5 \%$, and $10 \%$ level, respectively.

\begin{tabular}{|c|c|c|c|c|c|}
\hline & $(1)$ & $(2)$ & $(3)$ & $(4)$ & $(5)$ \\
\hline \# of Funds & $\begin{array}{c}1.089^{* * *} \\
{[13.36]}\end{array}$ & & & & \\
\hline \# of Advisers & & & $\begin{array}{c}1.181^{* * *} \\
{[10.53]}\end{array}$ & $\begin{array}{c}1.179 * * * \\
{[10.41]}\end{array}$ & $\begin{array}{c}1.135 * * * \\
{[9.55]}\end{array}$ \\
\hline \# of Funds - Low(1-3) & & $\begin{array}{c}1.605^{* * *} \\
{[10.19]}\end{array}$ & & & \\
\hline \# of Funds - Mid (4-20) & & $\begin{array}{c}1.152^{* * *} \\
{[18.15]}\end{array}$ & & & \\
\hline \# of Funds $-\operatorname{High}(21+)$ & & $\begin{array}{c}1.019^{* * *} \\
{[4.77]}\end{array}$ & & & \\
\hline Director Return & & & & $\begin{array}{c}1.087^{* *} \\
{[2.56]}\end{array}$ & \\
\hline Past Failures & & & & $\begin{array}{c}0.908^{* *} \\
{[-2.42]}\end{array}$ & \\
\hline Directorship Firm & & & & & $\begin{array}{c}2.589^{* * *} \\
{[8.43]}\end{array}$ \\
\hline \# of Funds - Directorship Firm & & & & & $\begin{array}{c}1.002^{* *} \\
{[2.36]}\end{array}$ \\
\hline Time FE & Yes & Yes & Yes & Yes & Yes \\
\hline Pseudo R2 & 0.188 & 0.232 & 0.181 & 0.183 & 0.212 \\
\hline Observations & 15,766 & 15,766 & 15,766 & 15,766 & 15,766 \\
\hline
\end{tabular}




\section{Table 4}

\section{Director Level Hiring Determinants - Robustness}

We use a logit model to predict the probability that a hedge fund director is hired in the subsequent quarter. The unit of observation is a director-quarter from the sample of outside hedge fund directors. In Panel A, we repeat Model 3 of Table 3 but partition on the six most common countries for director residency. In Panel B, we partition our data on the sample of directors that provide profiles on LinkedIn. The coefficients are presented as odds ratios. All independent variables are defined in Table A.1. We include time fixed effects and cluster our standard errors at the director level. ***, ${ }^{* *}$, and ${ }^{*}$ represent statistical significance at the $1 \%, 5 \%$, and $10 \%$ level, respectively.

Panel A: Subsample by Director Country of Residence

\begin{tabular}{ccccccc}
\hline & U.S. & U.K. & Ireland & Cayman Is. & Bermuda & B.V.I. \\
\hline \# of Advisers & $1.210^{* * *}$ & $1.340^{* * *}$ & $1.415^{* * *}$ & $1.117^{* * *}$ & $1.168^{* * *}$ & $1.248^{* * *}$ \\
& {$[3.72]$} & {$[11.34]$} & {$[9.22]$} & {$[7.18]$} & {$[6.12]$} & {$[6.97]$} \\
\hline Time FE & Yes & Yes & Yes & Yes & Yes & Yes \\
Pseudo $R^{2}$ & 0.0765 & 0.194 & 0.0887 & 0.196 & 0.189 & 0.281 \\
Observations & 3,701 & 957 & 896 & 2,102 & 1,004 & 187 \\
\hline
\end{tabular}

Panel B: LinkedIn Subsample

\begin{tabular}{ccc}
\hline & $(1)$ & $(2)$ \\
\hline Female & 1.147 & 0.778 \\
& {$[0.54]$} & {$[-0.95]$} \\
Age & $0.719^{* * *}$ & $0.816^{* *}$ \\
& {$[-3.12]$} & {$[-2.16]$} \\
Top 100 University & 0.977 & 0.969 \\
& {$[-0.09]$} & {$[-0.15]$} \\
CFA & 1.352 & 1.006 \\
Graduate Degree & {$[0.79]$} & {$[0.02]$} \\
& 1.070 & 1.226 \\
CEO Experience & {$[0.19]$} & {$[0.77]$} \\
& 0.771 & 0.671 \\
PE Experience & {$[-0.60]$} & {$[-1.38]$} \\
& 1.083 & $1.556^{*}$ \\
Law Experience & {$[0.26]$} & {$[1.73]$} \\
& 1.020 & 1.235 \\
Fund Experience & {$[0.09]$} & {$[1.18]$} \\
& {$\left[255^{* * *}\right.$} & $1.476^{* * *}$ \\
Accounting Experience & 1.306 & {$[2.97]$} \\
& {$[1.26]$} & 1.174 \\
\# of Advisers & & $1.160^{* * *}$ \\
& & {$[8.46]$} \\
\hline Time FE & Yes & Yes \\
Pseudo $R^{2}$ & 0.0292 & 0.190 \\
Observations & 6,167 & 6,167 \\
\hline
\end{tabular}


Table 5

Director Selection and Fund Specific Human Capital

We use conditional logit models to predict the probability that a hedge fund director is hired in the subsequent quarter. The dependent variable is equal to one for the actual director that was hired and zero for the randomly drawn directors that form the control group. To form the random control group, for each hiring decision, we randomly draw 100 (with replacement) directors from the set of all outside directors that were available to be hired at that time. The conditional logit is grouped by hiring decision. All independent variables are defined in Table A.1. Our standard errors are clustered at the director level. ${ }^{* * *},{ }^{* *}$, and ${ }^{*}$ represent statistical significance at the $1 \%, 5 \%$, and $10 \%$ level, respectively.

\begin{tabular}{|c|c|c|c|c|c|c|}
\hline & (1) & $(2)$ & $(3)$ & $(4)$ & $(5)$ & (6) \\
\hline Experience with Adviser & $\begin{array}{c}5.196^{* * *} \\
{[434]}\end{array}$ & $\begin{array}{l}3.398 * * * \\
{[3.58]}\end{array}$ & $\begin{array}{l}4.217^{* * *} \\
{[371]}\end{array}$ & $5.048^{* * *}$ & $3.306^{* * *}$ & $\begin{array}{c}4.139^{* * *} \\
{[370]}\end{array}$ \\
\hline Experience with Administrator & $\begin{array}{c}2.267^{* * * *} \\
{[5.93]}\end{array}$ & $\begin{array}{c}2.047^{* * *} * \\
{[4.51]}\end{array}$ & $\begin{array}{c}2.470^{* * *} \\
{[5.74]}\end{array}$ & $\begin{array}{c}2.411^{* * * *} \\
{[6.29]}\end{array}$ & $\begin{array}{c}2.160^{* * *} \\
{[4.77]}\end{array}$ & $\begin{array}{c}2.616^{* * *} \\
{[5.75]}\end{array}$ \\
\hline Experience with Other Service Providers & $\begin{array}{l}1.205^{*} \\
{[1.73]}\end{array}$ & $\begin{array}{l}1.125 \\
{[0.92]}\end{array}$ & $\begin{array}{c}1.259^{*} \\
{[1.89]}\end{array}$ & $\begin{array}{l}1.342^{* *} \\
{[2.57]}\end{array}$ & $\begin{array}{c}1.270^{*} \\
{[1.79]}\end{array}$ & $\begin{array}{l}1.408^{* * *} * \\
{[2.72]}\end{array}$ \\
\hline Director Portfolio Correlation & $\begin{array}{l}3.074^{* * *} \\
{[8.71]}\end{array}$ & $\begin{array}{l}4.417^{* * *} * \\
{[9.60]}\end{array}$ & $\begin{array}{l}3.054^{* * *} \\
{[6.93]}\end{array}$ & $\begin{array}{l}3.042^{* * *} \\
{[8.74]}\end{array}$ & $\begin{array}{c}4.403^{* * *} \\
{[9.63]}\end{array}$ & $\begin{array}{l}3.033^{* * *} \\
{[6.93]}\end{array}$ \\
\hline Local Director & $\begin{array}{l}4.286^{* * *} \\
{[8.30]}\end{array}$ & $\begin{array}{l}4.529 * * * \\
{[7.89]}\end{array}$ & $\begin{array}{l}4.489^{* * *} \\
{[7.49]}\end{array}$ & $\begin{array}{l}5.135^{* * *} * \\
{[10.06]}\end{array}$ & $\begin{array}{l}5.412^{* * *} \\
{[9.61]}\end{array}$ & $\begin{array}{l}5.320^{* * *} \\
{[9.13]}\end{array}$ \\
\hline \# of Advisers $\times$ Fund Return & & $\begin{array}{c}1.044^{*} \\
{[1.73]}\end{array}$ & & & & \\
\hline \# of Advisers $\times$ Fund Regulatory Violation & & & $\begin{array}{c}0.884^{* *} \\
{[-2.04]}\end{array}$ & & & \\
\hline$\#$ of Funds $\times$ Fund Return & & & & & $\begin{array}{l}1.020^{*} \\
{[1.84]}\end{array}$ & \\
\hline$\#$ of Funds $\times$ Fund Regulatory Violation & & & & & & $\begin{array}{c}0.907^{* * *} \\
{[-2.62]}\end{array}$ \\
\hline \# of Advisers & $\begin{array}{l}1.135^{* * *} \\
{[6.14]}\end{array}$ & $\begin{array}{l}1.116^{* * *} \\
{[5.07]}\end{array}$ & $\begin{array}{c}1.133^{* * *} \\
{[5.06]}\end{array}$ & & & \\
\hline \# of Funds & & & & $\begin{array}{c}1.059^{* * *} \\
{[4.45]}\end{array}$ & $\begin{array}{c}1.050^{* * *} \\
{[3.81]}\end{array}$ & $\begin{array}{c}1.056^{* * * *} \\
{[3.97]}\end{array}$ \\
\hline Hiring Level FE & Yes & Yes & Yes & Yes & Yes & Yes \\
\hline Pseudo $\mathrm{R}^{2}$ & 0.318 & 0.322 & 0.317 & 0.298 & 0.300 & 0.299 \\
\hline Observations & 138,471 & 88,779 & 98,071 & 138,471 & 88,779 & 98,071 \\
\hline
\end{tabular}




\section{Table 6 \\ Fund Flows and Director Exits}

We model the relationship between funds flows and the loss of an outside director. The unit of observation is a hedge fund - quarter. The dependent variable is the funds' quarterly, implied net flow. Independent Exit w/o Replacement (EXIT) takes on a value of one if the fund loses, and is unable to replace, at least one director that serves across multiple advisers, and zero otherwise. In Model 2, we drop the first 18 months of the fund's life to mitigate incubation bias. In Model 3 , we only include funds with redemption notice periods of one quarter or less. In Model 4, we exclude funds in the bottom quintile of style-adjusted returns in the current quarter. In Model 5, Independent Exit w/ Replacement, that takes on a value of one if the fund loses, but replaces the exiting independent director, and zero otherwise. In Model 6, Non-Independent Exit takes on a value of one if the fund loses a director that does not serve across multiple advisers, and zero otherwise. In Models 7 and 8, respectively, we interact Exit with the number of external advisers and the number of external funds the exiting director serves on in the prior quarter. Each of these independent variables are lagged one quarter and defined in Table A.1. We include style, time,

and jurisdiction fixed effects. Our standard errors are clustered at the fund level. ***, **, and * represent statistical significance at the $1 \%, 5 \%$, and $10 \%$ level, respectively. 


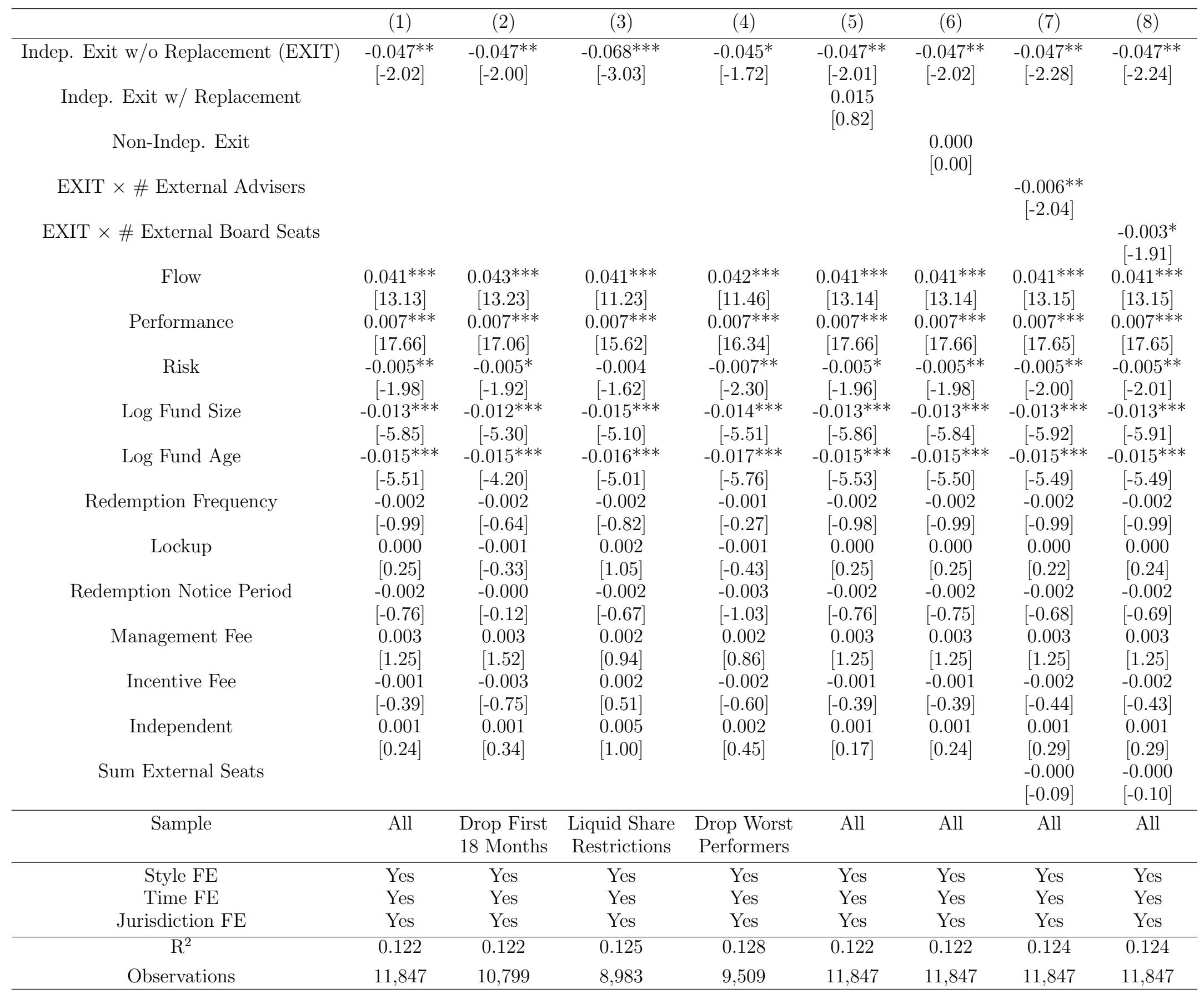




\section{Table 7}

\section{Independent Directors and Incidence of Fraud}

We use a logit model to predict the probability that a hedge fund engages in fraudulent activity. We obtain the dates that a hedge fund fraud occurs during the SEC's administrative proceedings. The unit of observation is a fund-quarter. All independent variables are defined in Table A.1. We include time fixed effects and cluster our standard errors at the fund level. ${ }^{* * *},{ }^{* *}$, and ${ }^{*}$ represent statistical significance at the $1 \%, 5 \%$, and $10 \%$ level, respectively.

\begin{tabular}{|c|c|c|c|}
\hline & (1) & $(2)$ & $(3)$ \\
\hline Has Independent & $\begin{array}{c}0.172^{* * *} \\
{[-5.31]}\end{array}$ & & \\
\hline \# External Board Seats & & $\begin{array}{c}0.101^{* *} \\
{[-2.00]}\end{array}$ & \\
\hline \# External Advisers & & & $\begin{array}{c}0.041^{* *} \\
{[-2.10]}\end{array}$ \\
\hline Female & $\begin{array}{c}0.090 * * * \\
{[-3.80]}\end{array}$ & $\begin{array}{c}0.297^{* *} \\
{[-2.15]}\end{array}$ & $\begin{array}{c}0.321 * * \\
{[-2.04]}\end{array}$ \\
\hline Board Age & $\begin{array}{l}1.003 \\
{[0.18]}\end{array}$ & $\begin{array}{c}0.994 \\
{[-0.32]}\end{array}$ & $\begin{array}{c}0.978 \\
{[-0.84]}\end{array}$ \\
\hline \# Directorship Firms & $\begin{array}{c}0.237^{* *} \\
{[-2.21]}\end{array}$ & $\begin{array}{c}0.247^{* * *} \\
{[-3.13]}\end{array}$ & $\begin{array}{c}0.293^{* * *} \\
{[-3.10]}\end{array}$ \\
\hline Director Network Overlap & $\begin{array}{c}1.023^{* * *} \\
{[2.89]}\end{array}$ & $\begin{array}{c}1.063^{* * *} \\
{[2.58]}\end{array}$ & $\begin{array}{c}1.074^{* * *} \\
{[2.84]}\end{array}$ \\
\hline Log Fund Size & $\begin{array}{c}1.187^{* *} \\
{[2.15]}\end{array}$ & $\begin{array}{c}1.163^{* *} \\
{[1.97]}\end{array}$ & $\begin{array}{c}1.153^{*} \\
{[1.79]}\end{array}$ \\
\hline Log Minimum Investment & $\begin{array}{c}0.784^{* * *} \\
{[-11.28]}\end{array}$ & $\begin{array}{c}0.788^{* * *} \\
{[-11.67]}\end{array}$ & $\begin{array}{c}0.797^{* * *} \\
{[-12.68]}\end{array}$ \\
\hline Reports to Database & $\begin{array}{c}0.424^{* *} \\
{[-2.08]}\end{array}$ & $\begin{array}{c}0.432^{* *} \\
{[-2.09]}\end{array}$ & $\begin{array}{c}0.392^{* *} \\
{[-2.43]}\end{array}$ \\
\hline Time FE & Yes & Yes & Yes \\
\hline Jurisdiction FE & Yes & Yes & Yes \\
\hline Pseudo $\mathrm{R}^{2}$ & 0.548 & 0.549 & 0.560 \\
\hline Observations & 37,829 & 37,829 & 37,829 \\
\hline
\end{tabular}




\section{Table 8}

\section{Independent Directors and Risk Shifting}

We model the relationship between changes in risk, performance, and board independence/reputation. The unit of observation is a hedge fund - year. The dependent variable, $\Delta R i s k$, is the difference in the standard deviations of the fund's monthly returns between the first half and second half of the calendar year. BOARD refers to one of our three board reputation proxies: Has Independent, \# External Funds, and \# External Advisers. Perf June, refers to the fractional rank (within style) of the fund's percentage distance to its HWM as of the end of June. All other independent variables are defined in Table A.1. The table reports standardized coefficients. Each model includes time fixed effects and standard errors clustered at the fund level. ${ }^{* * *}, * *$, and $*$ represent statistical significance at the $1 \%, 5 \%$, and $10 \%$ level, respectively.

Dependent variable: $\Delta$ Risk

(1)

(2)

(3)

\begin{tabular}{|c|c|c|c|}
\hline BOARD Definition: & Has Independent & \# External Board Seats & \# External Advisers \\
\hline \multirow[t]{2}{*}{ BOARD } & $-0.130^{*}$ & $-0.091^{* *}$ & $-0.072^{*}$ \\
\hline & {$[-1.71]$} & {$[-2.46]$} & {$[-1.88]$} \\
\hline \multirow[t]{2}{*}{ Perf June $_{\text {Jun }}$} & $-0.296 * * *$ & $-0.263^{* * *}$ & $-0.264^{* * *}$ \\
\hline & {$[-4.16]$} & {$[-6.12]$} & {$[-6.12]$} \\
\hline \multirow[t]{2}{*}{$\mathrm{BOARD}^{*}$ Perf $_{\text {June }}$} & 0.049 & $0.099 * * *$ & $0.099 * * *$ \\
\hline & {$[0.56]$} & {$[2.61]$} & {$[2.62]$} \\
\hline \multirow{2}{*}{ RiskJan.-June $_{\text {Jan }}$} & $-1.322^{* * *}$ & $-1.325^{* * *}$ & $-1.324^{* * *}$ \\
\hline & {$[-18.16]$} & {$[-18.30]$} & {$[-18.29]$} \\
\hline \multirow[t]{2}{*}{ Log Fund Size } & $-0.125^{* * *}$ & $-0.128^{* * *}$ & $-0.128^{* * *}$ \\
\hline & {$[-2.87]$} & {$[-2.96]$} & {$[-2.95]$} \\
\hline \multirow[t]{2}{*}{$\Delta \mathrm{AR}(1)$} & $-0.287 * * *$ & $-0.296^{* * *}$ & $-0.295^{* * *}$ \\
\hline & {$[-6.42]$} & {$[-6.64]$} & {$[-6.61]$} \\
\hline \multirow[t]{2}{*}{ Flow July-Dec. } & 0.271 & 0.278 & 0.273 \\
\hline & {$[0.88]$} & {$[0.90]$} & {$[0.88]$} \\
\hline \multirow[t]{2}{*}{ Log Fund Age } & -0.075 & -0.073 & -0.075 \\
\hline & {$[-1.34]$} & {$[-1.32]$} & {$[-1.35]$} \\
\hline \multirow[t]{2}{*}{ Log Minimum Investment } & $-0.081^{*}$ & -0.070 & -0.071 \\
\hline & {$[-1.84]$} & {$[-1.59]$} & {$[-1.60]$} \\
\hline \multirow[t]{2}{*}{ Redemption Frequency } & $0.108^{* *}$ & $0.104^{* *}$ & $0.106^{* *}$ \\
\hline & {$[2.37]$} & {$[2.35]$} & {$[2.40]$} \\
\hline \multirow[t]{2}{*}{ Lockup } & 0.052 & 0.057 & 0.054 \\
\hline & [1.17] & [1.28] & {$[1.22]$} \\
\hline \multirow[t]{2}{*}{ Redemption Notice Period } & $-0.141^{* * *}$ & $-0.146^{* * *}$ & $-0.147^{* * *}$ \\
\hline & {$[-3.47]$} & {$[-3.61]$} & {$[-3.62]$} \\
\hline \multirow[t]{2}{*}{ Leverage } & 0.045 & 0.044 & 0.046 \\
\hline & {$[1.19]$} & {$[1.17]$} & {$[1.20]$} \\
\hline \multirow[t]{2}{*}{ Incentive Fee } & 0.065 & 0.077 & 0.074 \\
\hline & {$[1.10]$} & {$[1.28]$} & {$[1.23]$} \\
\hline \multirow[t]{2}{*}{ Management Fee } & 0.027 & 0.022 & 0.023 \\
\hline & {$[0.67]$} & {$[0.56]$} & {$[0.59]$} \\
\hline Time FE & Yes & Yes & Yes \\
\hline $\mathrm{R}^{2}$ & 0.487 & 0.489 & 0.489 \\
\hline Observations & 2,246 & 2,246 & 2,246 \\
\hline
\end{tabular}




\section{Internet Appendix}

\section{IA.1. Regulation D of the Securities Act of 1933}

The Securities Act of 1933 ('33 Act) requires any offer to sell securities to U.S. investors be registered with the SEC. Regulation D of the '33 Act contains exemptions from the registration requirements, allowing companies to offer and sell their securities without having to register with the SEC. Of these exemptions, hedge funds typically rely on Rule 506, which regulates solicitation or advertising of the securities and requires the securities be offered to accredited investors. ${ }^{1}$ In doing so, funds are able to offer an unlimited amount of securities to investors by filing a Form D indicating the sale. In filing the Form D, funds must disclose their exemptions that enable them to avoid being defined as an "investment company" under the Investment Company Act of 1940 ('40 Act). Hedge funds primarily rely on two exemptions: Section 3(c)(1) and Section 3(c)(7). Under Section 3(c)(1), the issuer must not have more than 100 investors and must only sell securities to accredited investors. ${ }^{2}$ Funds with more than 100 investors must rely on the Section 3(c)(7) exemption which limits the fund to no more than 500 investors and requires the more rigorous qualified purchaser standard.

In March of 2009, the SEC implemented amendments to Reg D, requiring an electronic filing of the form. ${ }^{3}$

\footnotetext{
${ }^{1}$ For a more complete description of Rule 506, see:http://www.sec.gov/answers/rule506.htm.

${ }^{2}$ The accredited investor standard requires natural persons to have a liquid net worth of more than $\$ 1$ million or income of $\$ 200,000$ or more in each of the two most recent years or joint income with a spouse of $\$ 300,000$ over each of the previous two years. The qualified purchaser standard requires a natural person to have more than $\$ 5$ million in investments or an investment manager to have more than $\$ 25$ million in assets under management.

${ }^{3}$ More complete analysis of the amended Reg D filing can be found at: http://www.sec.gov/rules/final/ 2008/33-8891fr.pdf) The fund is required to file the notice within 15 days after the first sale of securities, is required to amend the filing when a material change has occurred, and annually thereafter.
} 


\section{IA.2. Offshore jurisdictions and boards of directors}

Hedge funds routinely create offshore vehicles for privacy and tax purposes. ${ }^{4}$ Managers looking to attract U.S.-based investors will often choose to use a master/feeder structure. A typical structure will consist of three entities: an onshore limited partnership feeder fund through which U.S. taxable investors can enter the fund; an offshore feeder fund, typically set up as an exempted corporation, through which non-U.S. and U.S. tax-exempt investors can enter the fund; and an offshore corporate master fund through which all trading activity is carried out.

For U.S. tax-exempt investors, the advantage of this approach is avoidance of Unrelated Business Taxable Income (UBTI). Under U.S. tax law, a tax-exempt organization (such as an ERISA-type retirement plan or endowment) that adopts an investment strategy where leverage is used is liable for UBTI. In offshore locales, however, the fund is set up as an exempted corporation rather than pass-through entity, such as a limited partnership. As such, the tax does not pass through to the investor, thus removing the burden on U.S. tax-exempt investors. For non-U.S. based investors, benefits include both possible tax-advantages from the home country, as well as privacy from disclosure laws in the U.S. For example, if offshore investors make any investments in U.S. securities, then U.S. withholding tax rules will apply and U.S. forms will have to be filled out to claim exemption from U.S. withholding taxes. The investors will have to submit these forms, which declares their participation, to U.S. tax authorities. Alternatively, if the offshore fund is structured as a corporation, then only the corporate entity will have to submit the paperwork, thus allowing its individual non-U.S. investors to remain anonymous to U.S. tax authorities.

Among the hedge funds in our sample, the most common domicile for offshore hedge funds is the Cayman Islands, which accounts for $79.6 \%$ of the sample. The next two largest

\footnotetext{
${ }^{4}$ Aragon, Liang, and Park (2014) study the differences in regulatory environment and investor clienteles between onshore and offshore funds.
} 
domiciles are the British Virgin Islands and Bermuda, respectively. Collectively, these three locales account for $91.4 \%$ of the offshore funds in our sample.

In the Cayman Islands, a fund typically creates a registered mutual fund and is subject to the requirements of the Cayman Islands Mutual Fund Law. ${ }^{5}$ These requirements include that the fund appoint at least two directors (in the Cayman Islands the two directors must be natural persons i.e. not a corporate entity) that the Cayman Islands Monetary Authority (CIMA) deems are fit and proper to be directors. Managers or officers of the fund are not precluded from serving as a director. Upon review of CIMA, any director not believed capable of fulfilling her duties may be forced to be replaced or the fund's registration with CIMA may be canceled. Non-CIMA registered funds in the Cayman Islands require only a single director.

Other jurisdictions have similar but not identical regulations regarding directors. In the British Virgin Islands, funds are only required to have one director, and the director does not have to be a natural person. In Bermuda, one director must be a resident of Bermuda.

\footnotetext{
${ }^{5}$ Note that the term mutual fund is generic and is distinct from the typical U.S.-based interpretation of a mutual fund. Further, while funds can avoid registration with CIMA by maintaining 15 or fewer accounts, the majority of whom are capable of appointing or removing the fund's operator, most funds fail to meet this requirement and choose to register. See the 2012 Mutual Fund Law: http://www. cimoney.com.ky/ WorkArea/DownloadAsset . aspx?id=2147483702
} 